BNL --45270

DE9 1005543

\title{
DEVELOPMENT OF POLYMER CONCRETE VAULTS \\ FOR NATURAL GAS REGULATOR STATIONS
}

\section{Jack J. Fontana, C. A. Miller, Walter Reams and David Elling}

\author{
August 1990
}

\author{
Prepared for \\ The Brooklyn Union Gas Company \\ 195 Montague Street \\ Brooklyn, New York 11201 \\ and the \\ Consolidated Edison Company of New York \\ 4 Irving Place \\ New York, NY 10003
}

\begin{abstract}
ENERGY EFFICIENCY AND
CONSERVATION DIVISION

DEPARTMENT OF APPLIED SCIENCE

BROOKHAVEN NATIONAL LABORATORY

ASSOCIATED UNIVERSITIFS, INC.
\end{abstract}

This work was performed under the auspices of the U.S. Department of Energy, Washington, D.C. Under Contract No. DE-AC02-76CN00016 
This report was prepared as an account of work sponsored by an agency of the United States Government. Neither the UnIted States Government nor any agency thereof, nor any of their employees, nor any of their contractors, subcontractors, or their employees makes any warranty, express or 1mplled, or assumes any legal liability or responsibility for the accuracy, completeness, or usefulncss of any information, apparatus, product or process disclosed, or represents that 1 ts use would not infringe privately owned rights. Reference hereln to any specific commerclal product, process, or service by trade name, trademark, manufacturer, or otherwise, does not necessarily constitute or imply its endorsement, recommendation, or favoring by the United States Government or any agency thereof. The views and opinlons of authors expressed herein do not necessarily state or reflect those of the United States Government or any agency, contractor, or subcontractor thereof. 


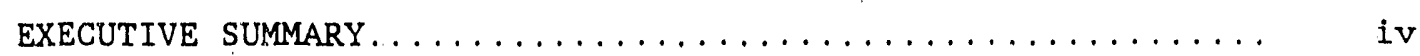

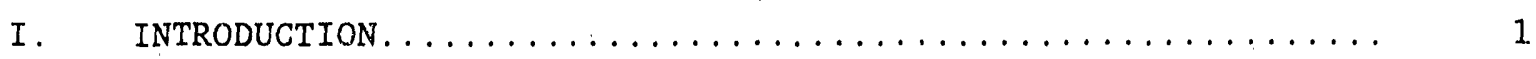

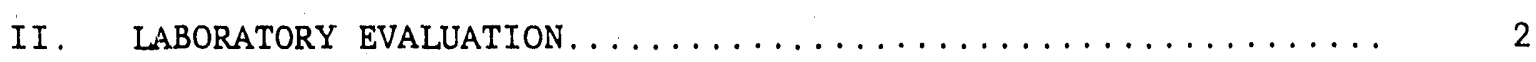

A. Effect of Silane Coupling Agent............. 2

B. Effect of Different Resins.................... 5

C. Cure Time vs Compression Strength............... 5

D. Effect of Fibers on Flexure Strength and Modulus....... 5

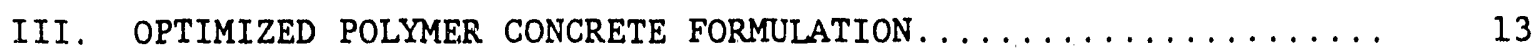

A. Flexure Strength........................ 13

B. Compression strength...................... 19

C. Water Absorption.......................... 19

D. Fire Resistance........................... 19

IV. INSTALling PENETRATIONS IN POLYMER CONCRETE VAULTS ......... 21

V. INSTALIING COVERS ON POLYMER CONCRETE VAULTS ........... 27

A. The Brooklyn Union Gas Company................ 27

B. Consolidated Edison Company of New York........... 28

VI. DESIGN OF POLYMER CONCRETE PRECAST VAULTS............... 29

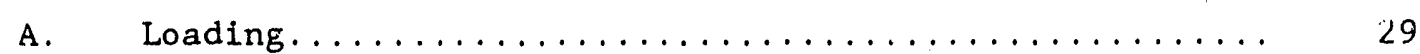

1. Forces on Cover......................... 30

2. Forces on Sidewalls.................... 30

3. Forces on Foundation Slab................ 31

B. Material Properties............................... 32

C. Stress Evaluations....................... 33

D. Experimental Verification.......................... 33

E. Designs............................. 37

1. The Brooklyn Union Gas Company.............. 37

2. Consolidated Edison of New York............. 40

VII. ADDITIONAL BALIAST TO PREVENT BUOYANCY OF THE VAULT........ 42

VIII. SPECIFICATIONS FOR PRECAST POLYMER CONCRETE VAULTS ........ 43

A. Material Design Formulation................ 43

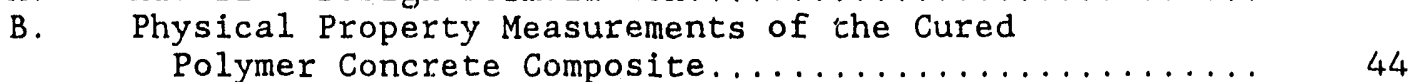

IX. Manufacture of Polymer Concrete Vaults............... 45

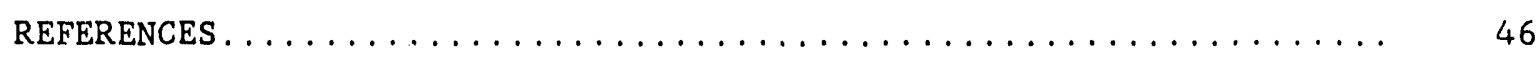

AFPENDIX A DRAWINGS JF BUG AND CON ED POLYMER CONCRETE VAULTS

APPENDIX B MATERIAL SUPPLIERS 
1. Mix designs for polymer concrete vaults...............

2. Effect of silane coupling agent on the compression strength of polymer composites......................... 4

3. Compression strength of polymer composices with different

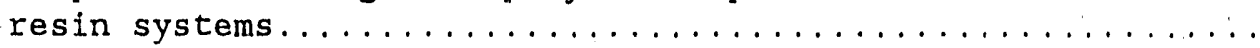

4. Flexure strength of polymer concrete with different resin

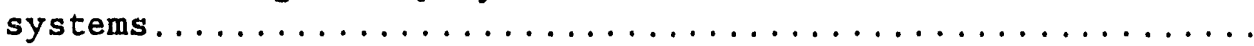

5. Effect of fibers on flexure stzength and modulus of polymer

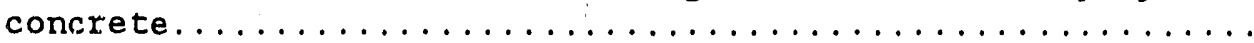

6. Effect of steel and glass fibers on the flexure strength of polymer concrete.........................

7. Effect of the aspect ratio of steel fibers on the ductility of polymer concrete......................... 12

8. Optimized polymer concrete mix design................ 14

9. Flexure strength for optimized polymer concrete mix design... 15

10. Flexure strength of epoxy polymer concrete............ 16

11. Compression strength of optimized polymer concrete mix design................................... 20

12. Fire resistance of optimized polymer concrete mix design.... 


\section{LIST" OF FITGURES}

Page

1. Compression strength vs cure time................. 8

2. Polymer concrete load deflection curves................ 18

3. Bonding of penetrations through rolymer conclete vaults.... 25

4. Hydrostatic testing of bonded yenetrations............. 26

5. Load-deflection curve for quarter scale model polymer

concrete vault............................. 36 
Vaults for natural gas regulator stations have traditionally been fabricated with steel-reinforced portland cement concrete. Since these vaults are installed below ground level, they are usually coated with a waterproofing material to prevent the ingress of moisture into the vault. In some cases, penetrations for piping that are normally cast into the vault do not line up with the gas lines in the streets. This necessitates off-setting the lines to line up with the penetrations in the vault or breaking out new. penetrations which could weaken the structure and/or allow water ingress. This can be costly since it involves additional labor during the vault installation.

By casting the vaults using a new material of construction such as polymer concrete, a longer maintenance free service life is possible because the physical and durability properties of polymer concrete composites are much superior to those of portland cement concrete. The higher strengths of polymer concrete allow the design engineer to reduce the wall, floor, and ceiling thicknesses making the vaults lighter for easier transportation and installation. Penetrations can be cut after casting to match existing street lines, thus making the vault more universal and reducing the number of vaults that are normally in stock.

The Process Materials Group of the Energy Efficiency and Conservation Division at Brookhaven National Laboratory (BNL) developed a steel-fiber reinforced polymer concrete composite that could be used for regulator vaults. Based on the physical properties of this new composite, vaults were designed to replace the BUG PV -008 and Con Ed GR-6 regulator vaults made of reinforced portland cement concrete. Quarter-scale models of the polymer concrete vaults were tested and the results reaffirmed the reduced wall thickness design.

Two sets of vaults were cast by Hardinge Bros., under contract to BNL, using the composite formulation developed at BNL. The vaults were inspected by representatives of the utilities and BNL, and were accepted for delivery. 


\author{
Development of Ṕolymer Concrete Vaults \\ for Natural Gas Reǵulator Stations \\ Jack J. Fontana, C. A. Miller, Walter Reams and David Elling \\ Energy Efficiency and Conservation Division \\ Brookhaven National Laboratory \\ Upton, New York 11973
}

\title{
I. INTRODUCTION
}

Vaults for natural gas regulator stations have traditionally been fabricated with steel-reinforced portland ce ant concrete (PCC). Since these vaults are installed below ground level, they are usually coated with a waterproofing material to prevent the Ingress of moisture into the vault. In some cases, penetrations for piping that are normally cast into the vault do not line up with the gas lines in the streets. This necessitates off-setting the lines to line up with the penetrations in the vault or breaking out new penetrations which could weaken the structure and/or allow water ingress. This can also be costly since it involves additional labor during the installation of the vaults. In addition, some of these vaults are very heavy $(>25,000 \mathrm{lbs})$ requiring the use of large cranes during installation.

With the advent of advanced materials of construction, such as polymer concrete $(\mathrm{PC})$, it may be possible to cast vaults that have longer maintenance-free service life because the physical and durability properties of PC are much higher than those of PCC [1]. The higher strengths will allow designers to reduce the wall thicknesses making the vaults lighter for easier transportation and installation. Penetrations will be cut after casting to match existing street lines, thus eliminating the need to have right and left handed vaults. 
The Materials Group of the Energy Efficiency and Conservation Division at Brookhaven National Laboratory (BNL) has developed numerous PC formulations that display a wide range of physical and thermal properties [2-4]. Some of these materials are presently being used in commercial applications, while others are still undergoing extensive testing both in the laboratory and in the field. Based on this experience, BNL has developed a PC formulation that can be used to precast vaults for natural gas regulator stations. The PC formulation optimizes the flexure and compression strengths so that a vault with a greatly reduced wall thickness could be designed. Steel fibers were included in the PC mix design to increase the flexural strength and allowable deflection.

\section{LABORATORY EVALUATION}

Samples were made of various mix designs to study the effect on the physical properties of the PC composite. Table 1 is a compilation of the original mix designs studied. Two resin systems were investigated.

A. Effect of Silane Coupling Agent

The effect of a silane coupling agent additive on the compression strength of polymer concrete was studied. Previous experience has indicated that the use of a silane coupling agent promotes the adhesion between the resin and aggregate, thus increasing the strength of the composite.

In Table 2, a series of four mix designs have been tabulated, two of these were made with silane and two without. The samples with the silane coupling agent had compression strengths that were 16 to 24 percent higher than equivalent samples without silane. 
TABLE' 1

MIX DESIGNS FOR POLYMER CONCRETE VAULTS

\begin{tabular}{|c|c|c|c|c|c|c|c|c|}
\hline $\begin{array}{l}\text { Mix } \\
\text { Design }\end{array}$ & $\operatorname{Resin} 1$ & $\begin{array}{l}\text { Resin } \\
\text { w58 }\end{array}$ & $\begin{array}{c}\text { Stone } \\
\text { wt8 }\end{array}$ & $\begin{array}{l}\text { Sand }^{3} \\
\text { Coarse } \\
\text { wt } 8\end{array}$ & $\begin{array}{l}\text { Sand }{ }^{4} \\
\text { Fine } \\
\text { wtz }\end{array}$ & $\begin{array}{l}\text { Silica } \\
\text { Flour } \\
\text { wto }\end{array}$ & $\begin{array}{l}\mathrm{BaSO}_{4} \\
\text { wto }\end{array}$ & $\begin{array}{c}\text { Fibers } \\
\text { wto }\end{array}$ \\
\hline 1 & 79-67LV & 10.3 & 38.5 & 30.7 & 15.4 & $5.1^{6}$ & & \\
\hline 2 & & 8.4 & 34.5 & 31.7 & 15.9 & 9.5 & r & \\
\hline 3 & & 9.4 & 34.0 & 34.0 & 17.0 & 5.6 & & \\
\hline 4 & & 9.4 & 33.9 & 33.9 & 16.9 & 5.9 & & \\
\hline $4 \mathrm{~A}$ & & 9.4 & $33.9^{7}$ & 33.9 & 16.9 & 5.9 & & \\
\hline 5 & & 9.6 & 32.0 & 32.0 & 16.0 & 5.6 & & $S 4.8^{8}$ \\
\hline 6 & & 11.4 & 32.5 & 32.5 & 16.3 & 5.7 & & G $1.6^{9}$ \\
\hline 7 & & 10.8 & 33.2 & 33.2 & 16.6 & 5.8 & & G 0.4 \\
\hline 8 & & 8.5 & 34.2 & 34.2 & 17.1 & 6.0 & & \\
\hline 9 & & 10.7 & 32.8 & 32.8 & 16.4 & 5.7 & 1.6 & \\
\hline & $7517-8 A$ & & & & & & & \\
\hline 10 & & 10.8 & 33.3 & 33.3 & 16.8 & 5.8 & & \\
\hline
\end{tabular}

Notes: 1. 79-67LV, Dicyclopentadiene polyester

7517-8A, unsaturated orthophthalic polyester.

2. Stone $1 / 4-1 / 2$ inch sieve size.

3. Sand, coarse, 12 - 40 sieve size.

4. Sand, fine, $30-70$ sieve size.

5. Silica flour, 200-300 sieve size.

6. Fillite 200/7, 30-150 microns.

7. Emerycrete 1/8 - 1/4 sieve size.

8. S - steel fibers, 1 inch corrugated.

9. G - glass fibers, $1 / 2$ inch long. 


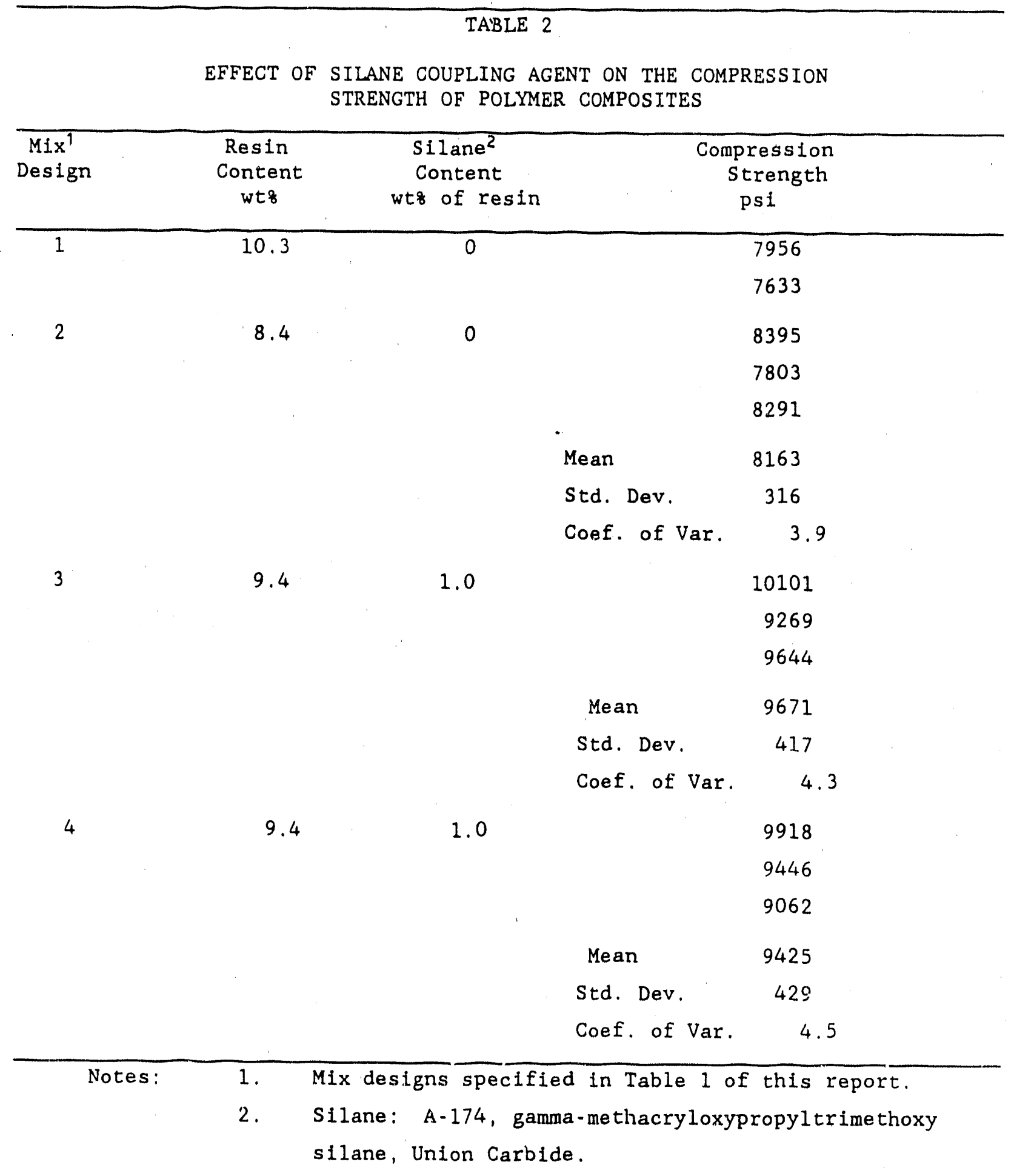


B. Effect of Different Resins :

A series of samples were made with two different resins to see what effect the resin type had on the compression strength of the composite. In Table 3, the data indicate that composites made with the orthophthalic unsaturated polyester resin from Reichhold Chemical Company have compression strengths that are 34 percent higher than composites made with the dicyclopentadiene polyester resin from the Alpha Corporation.

A series of beans were made with several different resins to measure the flexure strength of the composites. The results are presented in Table 4. The data indicate that polymer concretes made with an epoxy resin (Denepox 40) have higher flexure strengths than tirose made with poiyester resins. The cost of the epoxy resin, however, is 3 to 4 times higher than the cost of the polyesters and, therefore, it may not be cost-effective at this time.

C. Cure Time vs Compression Strength

The data in Table 3 indicate that the compression strength of the composites increase with time. A series of samples were made to measure the compression strength over a long period of tilne to determine the rate of strength increase. The mean compression strength as a function of cure time is plotted in Figure 1. The data indicate that the strength levels out after approximately 10 days. This type of behavior is not unusual sinct many freeradical polymerization reactions are known to continue for long periods of time at very slow rates.

D. Effect of Fibers on Flexure Strength and Modulus

A series of polymer concrete beams (2-in. by 2 -in. by $12-i n$.$) were$ made using glass or steel fibers. The glass fibers used were 1/2-in. long, the steel fibers were 1 -in. long corrugated fibers. 


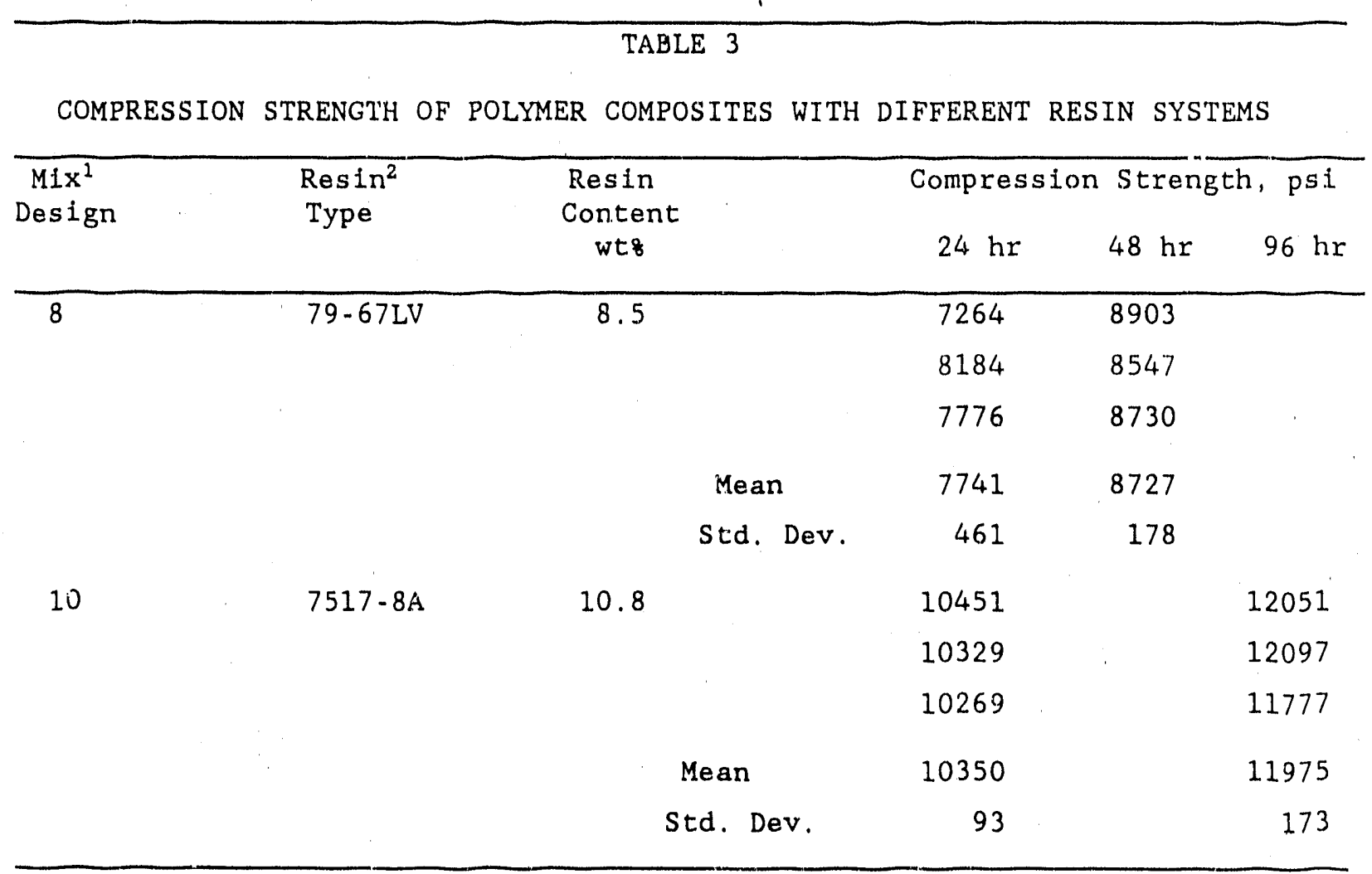

Notes: 1. Mix designs specified in Table 1 of this report.

2. 79-67 LV dicylopentadiene polyester from Alpha Corp. 7517-8A orthophthalic polyester from Reichhold Chemical Co. 


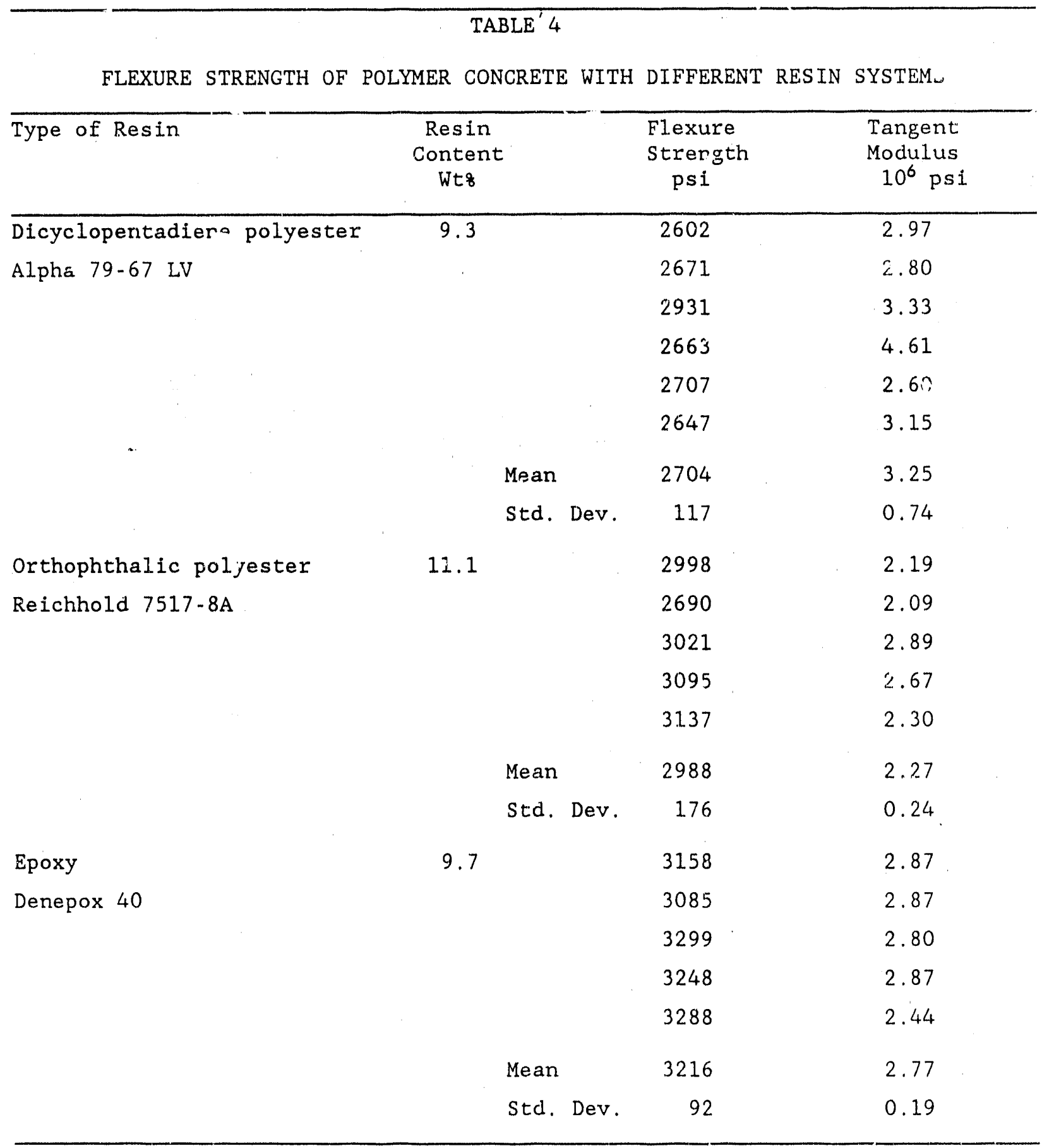




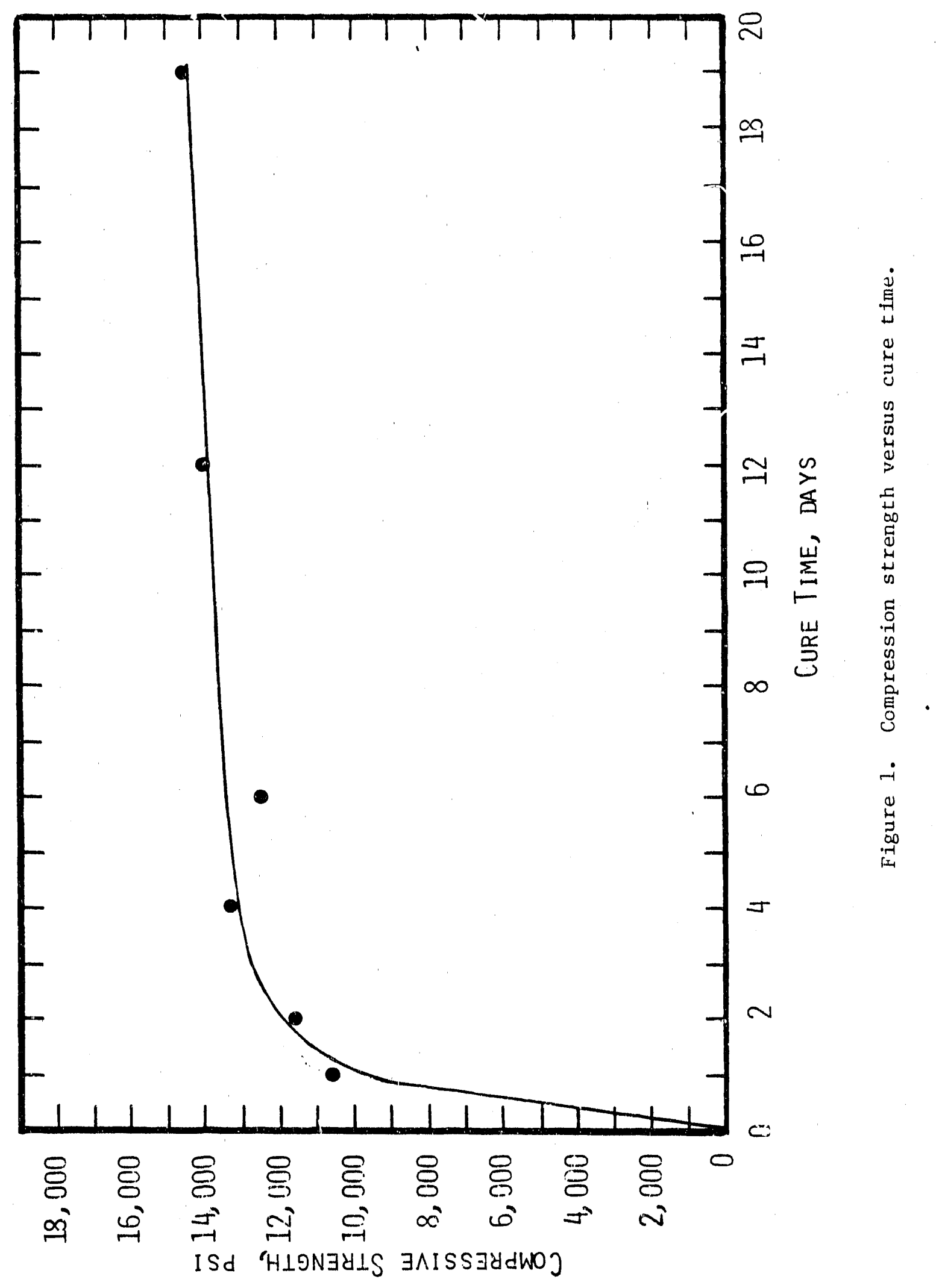


Two sets of beams were made with glass fibers. One set had 0.4 percent fibers based on the total weight of the composite, the second set had 1.6 percent fibers. A third set of beams were cast with 4.8 percent steel fibers. The flexure strengths and tangent modulii were compared with beams that did not contain any fibers.

The data (Table 5) indicate that there was no increase in the flexure strength of the beams containing glass or steel fibers at these ratios. However, there was a decrease in the tangent modulus which indicates that the ductility of the composite was increased. Additional samples were made with higher concentrations of glass and steel fibers.

The glass fiber courent was increased from 0.4 to 5.2 percent (Table 6). As the glass fiber content was increased, the resin content also had to be increased to improve the workability of the mix. Although there was an increase of 11 percent in the flexure strength of samples when the fiber content was increased from 0.4 to 2.2 percent, larger quantities of fiber actually indicated a loss of strength. At this point it was decided to eliminate the use of glass fibers.

The quantity of steel fibers was increased from 4.8 to 9.1 percent (Table 6). The flexure strength showed a markad increase of 35 percent by increasing the steel fiber content to 9.1 percent. However, it appeared that the steel fibers were pulling out of the composite without breaking. This indicates that the aspect ratio (length to width) of the 1 -in. fibers (aspect ratio 11) is too low to affect the ductility of the composite. A series of samples were made with $11 / 2$-in. fibers (aspect ratio 20) and this seemed to improve the ductility, although the flexus strength did not show any increase. These data are presented in Table 7. In addition, two series of samples were made with Bekaert fibers (ZL 30/.50) with an aspect ratio of 60 . These samples had flexure strengths that were slightly higher ( 2.7 fercent) than samples made with the $11 / 2$-in. Ribtec fibers, but the number of Bekaert fibers was 1.8 times the number of Ribtec fibers. The data indicate that either the 1 1/2-in. Ribtec or the ZL $30 / .50$ Bekaert fibers could be used for this project. However, additional work with the latter did not give the same results and, therefore, they are not recommended as a substitute for the Ribtec fibers at this time. 


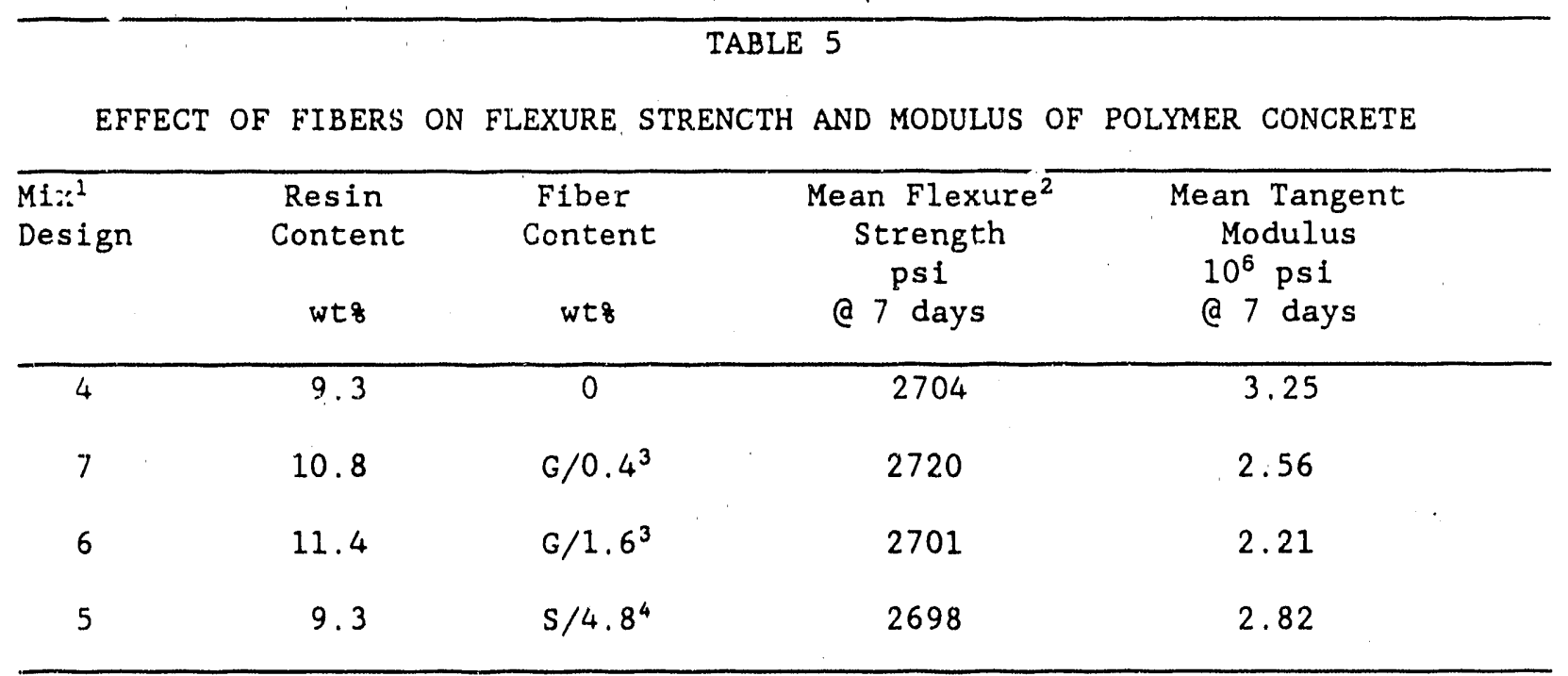

Notes: 1. Mix design specified in Table 1 of this report.

2. Averages of 6 samples.

3. Glass fibers $1 / 2$ inch long.

4. Steel fibers, corrugated, 1 inch long. 


\begin{tabular}{|c|c|c|c|c|}
\hline \multicolumn{5}{|c|}{$\begin{array}{c}\text { EFFECT OF STEEL AND GLASS FiBERS ON THE FLEXURE STRENGTH } \\
\text { AND MODULUS OF POLYMER CONCRETE }\end{array}$} \\
\hline $\begin{array}{l}\text { Resing } \\
\text { Content } \\
\text { wto }\end{array}$ & $\begin{array}{l}\text { Steel } \\
\text { Fiber } \\
\text { Content } \\
\text { wto }\end{array}$ & $\begin{array}{l}\text { Glass } \\
\text { Fiber } \\
\text { Content } \\
\text { wtz }\end{array}$ & $\begin{array}{c}\text { Flexure } \\
\text { Strength } \\
\text { psi }\end{array}$ & $\begin{array}{l}\text { Tangent } \\
\text { Modulus } \\
10^{6} \mathrm{psi}\end{array}$ \\
\hline 9.3 & 0 & 0 & 2704 & 3.25 \\
\hline $10.8^{3}$ & 0 & 0.4 & 2720 & 2.56 \\
\hline $11.4^{3}$ & 0 & 1.6 & 2701 & 2.21 \\
\hline $14.9^{3}$ & 0 & 2.2 & 2996 & 2.10 \\
\hline $17.4^{3}$ & 0 & 5.2 & 2245 & 1.46 \\
\hline 9.3 & 4.8 & 0 & 2698 & 2.82 \\
\hline $10.1^{3}$ & 9.1 & 0 & 3605 & 2.80 \\
\hline
\end{tabular}

Notes: 1. Resin used, Alpha 79-67 LV.

2. Flexure strength and tangent modulus based on 5 or 6 samples.

3. Resin contents increased to improve workability. 


\section{TABLE 7}

EFFECT OF THE ASPECT RATIO OF STEEL FIBERS ON THE DUCTILITY OF POLYMER CONCRETE

\begin{tabular}{|c|c|c|c|c|c|}
\hline $\begin{array}{l}\text { Fiber } \\
\text { Content } \\
\text { Wto }\end{array}$ & $\begin{array}{l}\text { Fiber } \\
\text { Type }\end{array}$ & $\begin{array}{l}\text { Aspect } \\
\text { Ratio }\end{array}$ & $\begin{array}{l}\text { Resin } \\
\text { Type }\end{array}$ & $\begin{array}{l}\text { Mean }^{3} \\
\text { Flexure } \\
\text { Strength } \\
\text { psi }\end{array}$ & $\begin{array}{l}\text { Mean } \\
\text { Tangent } \\
\text { Modulus } \\
10^{6} \text { psi }\end{array}$ \\
\hline 0 & 0 & 0 & $79-67 \mathrm{LV}$ & 2704 & 3.25 \\
\hline 4.8 & $\begin{array}{l}\text { Ribtec } \\
1 \text {-in. }\end{array}$ & 10 & $79-67 \mathrm{LV}$ & 2698 & 2.82 \\
\hline 9.1 & $\begin{array}{l}\text { Ribtec } \\
11 / 2 \text {-in. }\end{array}$ & 20 & $79-67 \mathrm{LV}$ & 3605 & 2.80 \\
\hline 0 & 0 & 0 & $7517-8 \mathrm{~A}$ & 2988 & 2.27 \\
\hline 9.1 & $\begin{array}{l}\text { Ribtec } \\
1 \text {-in. }\end{array}$ & 10 & $7517-8 \mathrm{~A}$ & 3581. & 2.45 \\
\hline 5.4 & $\begin{array}{l}\text { Bekaert } \\
\text { ZL } 30 / .50\end{array}$ & 60 & $79-67 \mathrm{LV}$ & 3703 & 3.56 \\
\hline
\end{tabular}

Notes: 1. Aspect ratio: length to width

2. $79.67 \mathrm{LV}$ - dicyclopentadiene polyester from Alpha Corp.

7517-8A orthophthalic polyester from Reichhold Chemical Co.

3. Mean flexure strength of 4 to 6 samples. 
III. OPTIMIZED PÓLYMER CONCRETE FORMULATION

The polymer concrete formulation was modified slightly to improve the workability, of the mix without effecting the physical properties of the composite. Any composite slurry containing 9 weight percent steel fibers will not flow easily, but with the proper vibration the mix will compact into a void-free mass. Composites with steel fiber contents above 10 weight percent have very poor workability and are considered impractical for commercial applications .

The optimized mix utilizes a graded silica sand and a crushed stone. Silica flour is used to facrease the flowability of the mix and to obtain a very low void mass. The moisture content of the coarse stone and the graded silica sand and silica flour must not exceed 0.5 weight percent. The optimized mix design is given in Table 8.

A. Flexure Strength (ASTM C-78)

Two different types of coarse aggregates were studied. A crushed traprock and a silica well-gravel. The crushed traprock ranged in size from $1 / 4$ to $1 / 2$ inch and the silica gravel from $1 / 8$ to $1 / 4$ inch. The maximum flexure strengths averaged $4684 \mathrm{psi}$ and $4426 \mathrm{psi}$ respectively with a corrugated steel fiber content of 9 weight percent. If the fiber content is reduced to 6.5 weight percent, the maximum flexure strength averages 3911 psi. This is approximately a 20 percent reduction in strength. These data are presented in Table 9. Samples made with the Bekaert steel fibers did not show the same flexure strength increases as had been previously noted (Table 7), therefore, they cannot be recommended for use at this time.

Several series of samples were made with epoxy resins with the same aggregate and fiber used for the polyester polymer concrete. In some cases the flexure strength of the epoxy polymer concretes was higher than the flexure strength of the polyester polymer c ncrete. The flexure strengths of seven series of samples are presented in Table 10. 


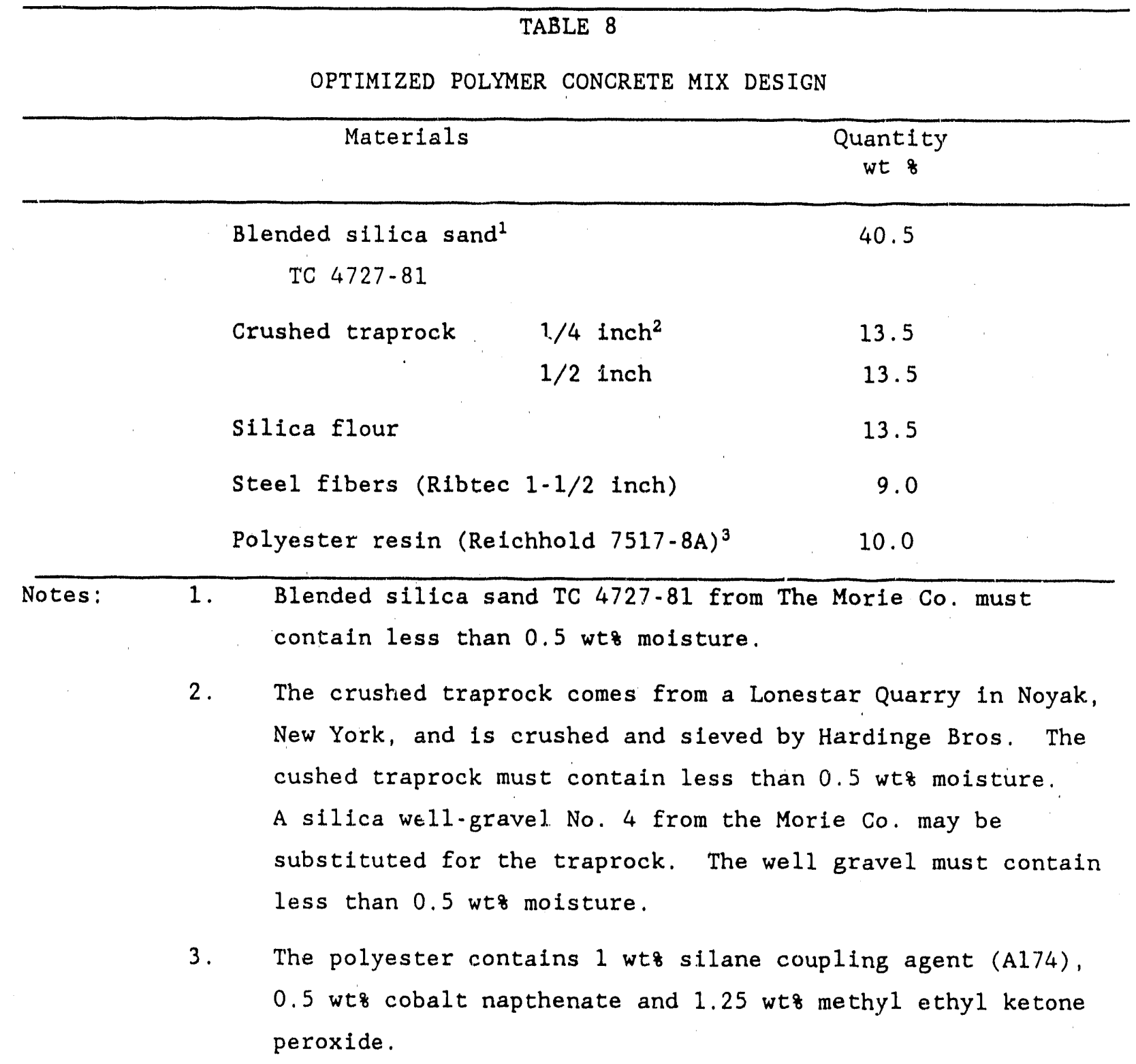


TABLE 9

FLEXURE STRENGTH FOR SEVERAL POLYMER CONCRETE MIX DESIGNS

\begin{tabular}{|c|c|c|c|c|c|c|c|}
\hline $\begin{array}{l}\text { Resin } \\
\text { wto }\end{array}$ & $\begin{array}{l}\text { Steel } \\
\text { Fiber } \\
\text { Type }\end{array}$ & $\begin{array}{l}\text { Steel } \\
\text { Fiber } \\
\text { Content } \\
\text { wts }\end{array}$ & $\begin{array}{l}\text { Crushed } \\
\text { Traprock } \\
\text { wtz }\end{array}$ & $\begin{array}{c}\text { Silica } \\
\text { Gravel } \\
\text { wto }\end{array}$ & $\begin{array}{l}\text { Flexure } \\
\text { Strength } \\
\text { psi }\end{array}$ & $\begin{array}{l}\text { Mean } \\
\text { Flexure } \\
\text { Strength } \\
\text { psi }\end{array}$ & $\begin{array}{r}\text { Stardard } \\
\text { Deviation }\end{array}$ \\
\hline $\begin{array}{l}7517-8 \mathrm{~A} \\
10.0 \text { wto } \\
\text { Polyester }\end{array}$ & $\begin{array}{l}\text { Ribtec } \\
11 / 2\end{array}$ & 6.5 & 28.0 & 0 & $\begin{array}{l}3179 \\
3752 \\
4503 \\
3875 \\
3845 \\
4314\end{array}$ & 3911 & 465 \\
\hline $\begin{array}{l}7517-8 \mathrm{~A} \\
10.0 \text { wt8 } \\
\text { Polyester }\end{array}$ & $\begin{array}{l}\text { Ribtec } \\
11 / 2\end{array}$ & 9.0 & 27.0 & 0 & $\begin{array}{l}5447 \\
5020 \\
4083 \\
4359 \\
4798 \\
4394\end{array}$ & 4684 & 502 \\
\hline $\begin{array}{l}7517-8 \mathrm{~A} \\
10.0 \text { wt } \\
\text { Polyester } \\
\end{array}$ & $\begin{array}{l}\text { Ribtec } \\
11 / 2\end{array}$ & 9.0 & 0 & 27.0 & $\begin{array}{l}3871 \\
4262 \\
5068 \\
3995 \\
4970 \\
4371\end{array}$ & 4426 & 496 \\
\hline $\begin{array}{l}7517-8 \mathrm{~A} \\
10.0 \text { wtz } \\
\text { Polyester }\end{array}$ & $\begin{array}{l}\text { Bekaert } \\
30 / .50\end{array}$ & 5.5 & 28.0 & 0 & $\begin{array}{l}3278 \\
3179 \\
3947 \\
2698 \\
3327 \\
3265\end{array}$ & 3282 & 399 \\
\hline $\begin{array}{l}7517-8 \mathrm{~A} \\
10.0 \text { wtz } \\
\text { Polyester }\end{array}$ & $\begin{array}{l}\text { Bekaert } \\
30 / .50\end{array}$ & 5.5 & 0 & 28.0 & $\begin{array}{l}3794 \\
2979 \\
3236 \\
3212 \\
3785 \\
3599\end{array}$ & 3434 & 339 \\
\hline
\end{tabular}




\begin{tabular}{|c|c|c|c|c|}
\hline \multirow[b]{2}{*}{$\begin{array}{l}\text { Date } \\
\text { Made }\end{array}$} & \multicolumn{3}{|c|}{$\begin{array}{ll} & \text { TABLE } 10 \\
\text { FLEXURE STRENGTH OF EPOXY }\end{array}$} & \multirow[b]{2}{*}{$\begin{array}{l}\text { Standard } \\
\text { Deviation }\end{array}$} \\
\hline & $\begin{array}{l}\text { Epoxy } \\
\text { Resir. }\end{array}$ & $\begin{array}{l}\text { Samples made } \\
\text { by }\end{array}$ & $\begin{array}{l}\text { Mean }^{4} \\
\text { Flexure Strength } \\
\text { Psi }\end{array}$ & \\
\hline $1 / 2 / 90$ & Flexolith A\&B & $\mathrm{BNZ}^{2}$ & 5146 & 270 \\
\hline $1 / 2 / 90$ & $\begin{array}{l}\text { Flexolith A } \\
\text { Duracrete B }\end{array}$ & BNL & 4366 & 554 \\
\hline $5 / 15 / 89$ & Flexolith $A \& B$ & BNL & 4234 & 566 \\
\hline $11 / 29 / 89$ & Flexocrete $A \& B$ & BNL & 5263 & 275 \\
\hline $10 / 10 / 89$ & Flexolith $A \& B$ & $\mathrm{HB}^{3}$ & 3985 & 296 \\
\hline $12 / 13 / 89$ & Flexocrete $A \& B$ & $\mathrm{HB}$ & 4662 & 338 \\
\hline $11 / 14 / 89$ & Flexolith $A \& B$ & $\mathrm{HB}$ & 3397 & 318 \\
\hline
\end{tabular}

Notes: $1 . \quad$ All samples made with formulation 1isted in Table 8.

2. BNL - Brookhaven National Iraboratory

3. $H B$ - Hardinge Brothers

4. Averages based on 3 to 6 samples 
The ductility of the epoxy polymer concrete was much lower than that of the polyester polymer concrete. Typical load-deflection curves are shown in Figure 2. The area under the load deflection curve beyond the yield point is at last ten times the area under the yield point for the polyester polymer concrete. This indicates that this composite is ductile. The load deflection curve of the epoxy polymer concrete indicates that this composite cannot maintain a load beyond the yield point and therefore, this composite is considered to be brittle.

In the polyester polymer concrete the load is transferred to the steel fibers and at the yield point they begin to carry most of the load. The steel fibers pull out of the polymer matrix as they are being loaded until the ultimate stress is reached at which point the samples can no longer carry any load. In the epoxy polymer concrete the load is also transferred to the steel fibers, however, the bond between the steel fibers and the epoxy resin is so good that the fibers cannot pull out of the matrix and break just beyond the yield point of the polymer concrete. This brittle behavior results in catastrophic fallure.

Most of the design processes were based upon simplifying assumptions that are acceptable when applied to ductile materials. Such discontinuities in box geometries as corners, lifting lugs and pipe penetrations result in stress concentrations that can easily be 5-10 times the average stress values used in the design. When a ductile material is so stressed, it will yield locally and redistribute the stress so that at ultimate fallure the stress distribution approaches that assumed in design. A brittle material, however, cannot redistribute the stress and will fail when the peak stress around the stress concentration points reaches the allowable limit. 


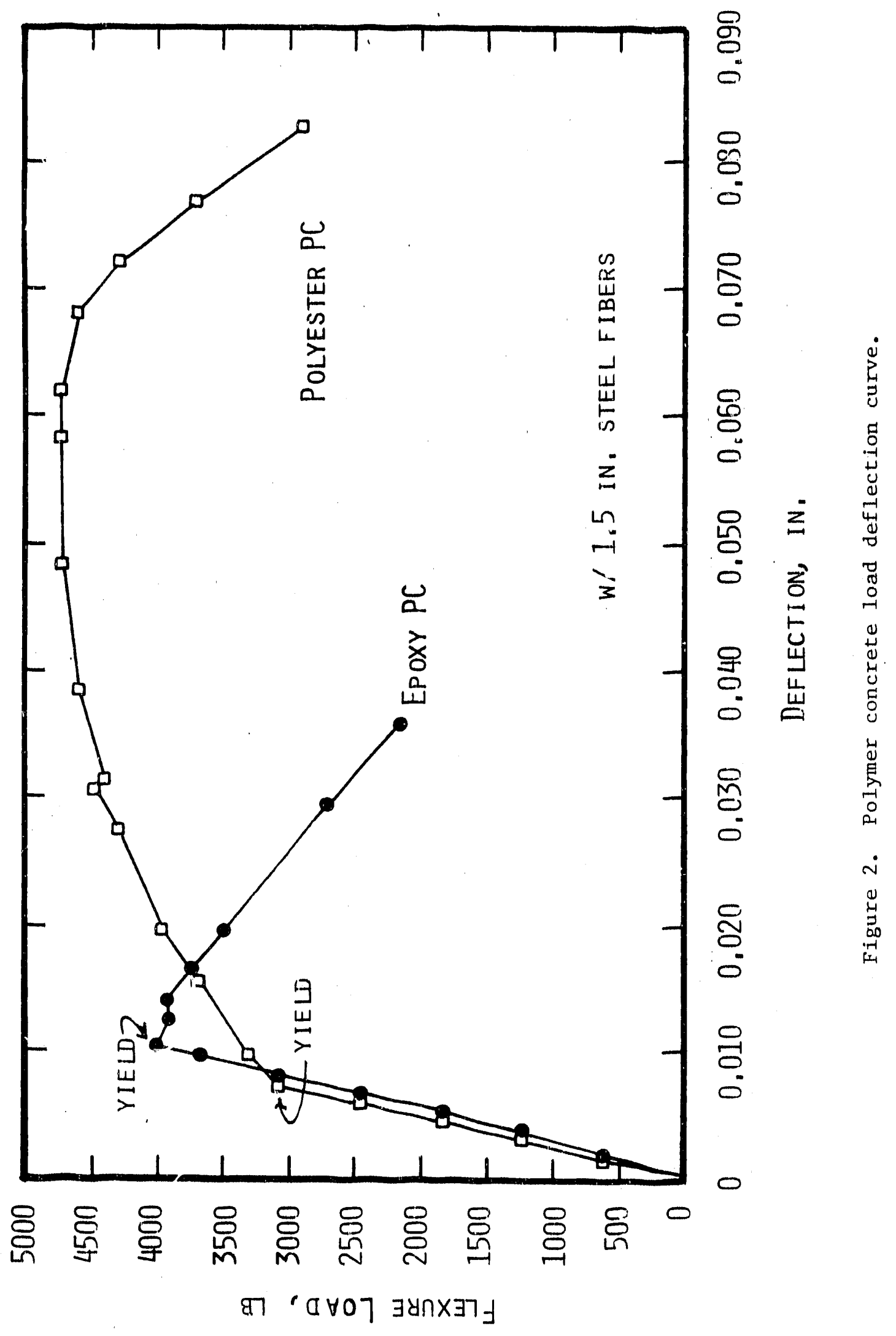


B. Compression strength (ASTM C-39)

The compression strength of the optimized polymer concrete mix design was measured for samples with both the crushed traprock and the silica gravel. The compression strength ranged from 14,800 to 16,000 psi (Table 11).

\section{Water Absorption}

The water absorption of the cured composite was obtained by submerging a block (2-in. by $8-i n$, by $8-i n$.) of polymer concrete in water for 24 hours at an ambient temperature of $72^{\circ} \mathrm{F}$ and measuring the weight increase.

The water absorption is calculated as follows:

Water absorption, percent $-\frac{W_{W}-W_{D}}{W_{\mathcal{D}}} \times 100$

where $W_{W}$ is the wet weight

$W_{D}$ is the dry weight

The water absorption measured was 0.12 percent. This low

absorption indicates that this composite will not need any additional coating to prevent water intrusion through the vault walls or floor.

\section{Fire Resistance}

There are no standard fire resistance tests for polymer concrete composites. One test that this laboratory has used in the past to compare different composites is based on ASTM D635. In this test, a $1 / 2$-inch by $1 / 2$ inch by 5 -inch long polymer concrete sample is held in a horizontal position. A propane torch is applied at one end for a period of 30 seconds and then removed. The time of burning of the composite is then measured. Once the flame goes out, the torch is reapplied and the test is repeated. This test compares one composite to another but is not intended to rate the fire resistance of a material. 


\section{TAB'LE 11}

COMPRESSION STRENGTH OF SEVERAL POLYMER CONCRETE MIX DESIGNS

\begin{tabular}{|c|c|c|c|c|c|}
\hline $\begin{array}{l}\text { Resin } \\
\text { wtz }\end{array}$ & $\begin{array}{l}\text { Steel } \\
\text { Fiber }\end{array}$ & $\begin{array}{l}\text { Steel } \\
\text { Fiber } \\
\text { Content } \\
\text { wto }\end{array}$ & $\begin{array}{c}\text { Crushed } \\
\text { Traprock } \\
\text { wto }\end{array}$ & $\begin{array}{c}\text { Silica } \\
\text { Gravel } \\
\text { wto }\end{array}$ & $\begin{array}{l}\text { Compression } \\
\text { Strength } \\
\text { psi }\end{array}$ \\
\hline $7517-8 \mathrm{~A}$ & Ribtec $11 / 2$ & 6.5 & 28.0 & 0 & 15,052 \\
\hline 10.0 wtz & & & & & 14,265 \\
\hline \multicolumn{6}{|l|}{ Polyesier } \\
\hline $7517-8 A$ & Ribtec $11 / 2$ & 9.0 & 27.0 & 0 & 16,088 \\
\hline 10.0 wtz & & & & & 15,920 \\
\hline \multicolumn{6}{|l|}{ Polyester } \\
\hline $7517-8 A$ & Ribtec $11 / 2$ & 9.0 & 0 & 27.0 & 15,042 \\
\hline \multicolumn{6}{|l|}{$10.0 \mathrm{wtz}$} \\
\hline \multicolumn{6}{|l|}{ Polyester } \\
\hline $7517-8 \mathrm{~A}$ & Bekaert & 5.5 & 28.0 & 0 & 14,839 \\
\hline $10.0 \mathrm{wtz}$ & $30 / .50$ & & & & 14,946 \\
\hline \multicolumn{6}{|l|}{ Polyester } \\
\hline $7517-8 A$ & Bekaert & 5.5 & 0 & 28.0 & 14,931 \\
\hline $10.0 \mathrm{wtz}$ & $30 / .50$ & & & & 14,976 \\
\hline Polyester & & & & & \\
\hline
\end{tabular}


By using the previously described procedure, several polymer concrete formulations were tested. Since the sample size is small, it was necessary to eliminate the coarse aggregate and the steel fibers from the samples. Two flame retardant agents were added to the mix design to see what their effect would be on the flame resistance of the composite. One of the flame retardants was alumina trihydrate (ATH). This is a white crystalline powder which gives off water molecules upon heating. The second flame retardant used was decabromodiphenyl oxide (DE83R, Great Lakes Co.). This is a white, free flowing powder that gives off a bromine compound upon heating.

In both cases, the flame retardant was added to the composite during the mixing operation. In general, the quantity of flame retardant required is proportional to the amount of resin in the system. A series of samples were made with the ATH and DE83R. These were tested as previously described and compared to an unmodified sample (Table 12).

Since the vaults are buried underground and the only possibility of a fire hazard would be from a ruptured gas line, it is not considered necessary to formulate the polymer concrete to include a flame retardant additive.

\section{INSTALLING PENETRATIONS IN POLYMER CONCRETE VAULTS}

In order to utilize the vaults for multiple applications, it was decided that the penetrations should not be cast in place. By installing the penetrations just prior to installing the vaults in the ground, it should be possible to locate the penetrations in the actual locations needed to match the existing gas lines. This method of installation would allow the utilization of one vault configuration for an infinite variety of penetration locations.

There were several criteria that had to be met to allow for the installation of the pipe penetrations after the vault was cast. 


\section{TAB'LE 12}

FIRE RESISTANCE OF SEVERAL POLYMER CONCRETE MIX DESIGNS

\begin{tabular}{|c|c|c|c|}
\hline $\begin{array}{l}\text { ATH } \\
\text { Resin } \\
\text { Ratio }\end{array}$ & $\begin{array}{l}\text { DE83R } \\
\text { Resin } \\
\text { Ratio }\end{array}$ & $\begin{array}{l}\text { Time of Burn for } \\
\text { First Ignition } \\
\text { seconds }\end{array}$ & $\begin{array}{c}\text { Time of Burn for } \\
\text { Second Ignition } \\
\text { seconds }\end{array}$ \\
\hline \multirow[t]{4}{*}{0} & 0 & 60 & 78 \\
\hline & & 60 & 84 \\
\hline & & 59 & 86 \\
\hline & & 73 & 90 \\
\hline \multirow[t]{4}{*}{1.5} & 0 & 2 & 9 \\
\hline & & 1 & 8 \\
\hline & & 0 & 6 \\
\hline & & 0 & 8 \\
\hline \multirow[t]{4}{*}{0} & 0.03 & 41 & 74 \\
\hline & & 43 & 71 \\
\hline & & 54 & 65 \\
\hline & & 56 & 62 \\
\hline \multirow[t]{4}{*}{0} & 0.1 & 7 & 44 \\
\hline & & 5 & 40 \\
\hline & & 6 & 34 \\
\hline & & 6 & 38 \\
\hline \multirow[t]{4}{*}{0} & 0.14 & 3 & 24 \\
\hline & & 2 & 9 \\
\hline & & 4 & 8 \\
\hline & & 3 & 6 \\
\hline
\end{tabular}


(1) It must be possible to core through the polymer concrete vault wall with a diamond core bit. This operation is easily accomplished. In general, it takes about 10 to 15 minutes to core a 3 -inch diameter hole through a 2inch thick polymer concrete slab reinforced with steel fibers. Generally, larger diameter core bits may take a little longer but even a 16 -inch diameter hole cored through a 4 -inch thick polymer concrete will probably not take more than 45 to 60 minutes.

(2) It must be possible to secure the pipe penetration in the cored hole so that it is water tight. Several polymer concrete slabs were cored and different methods were used to secure a iteel pipe in place. When the annulus between the outer wall of the pipe and the cored hole was $1 / 8$-inch or less, it was possible to fill the annulus with epoxy adhesive to bond the pipe in permanently. The pipe was placed in the center of the cored hole and held in position with clamps. A fillet of clay or silicon rubber was placed on one side of the wall to seal the gep between the pipe and the polymer concrete: The epoxy components were then mixed and placed in the annulus to completely fill the gap. Once the epory cured, the bond strength of the pipe to the polymer concrete slab was tested in stear as shown in Figure 3.

The shear stress at the bond line was calculated as follows:

$$
\text { Shear Stress }=\frac{\text { Load }}{\pi \mathrm{dl}}
$$

where,

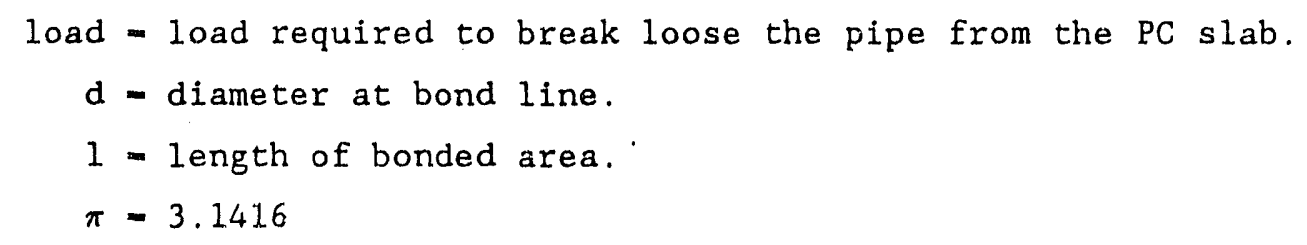


If the annulus between the outer wall of the pipe and the cored hole is greater than $1 / 8$ inch and as much as $i$ inch, it will be necessary to make an epoxy mortar to bond the pipe penetracion to the polymer concrete vault. The epoxy mortar can be made by mixing equal volumes of an epoxy gel (Flexolith gel, Dural International) and silica sand (No. OON, Morie Company).

A steel pipe with an outside diameter of 2.895 inches was "glued" in a 3-inch diameter hole in a polymer concrete slab using a fast setting epoxy gel (Poly-Plug, Dural International). Another sample was made using a very low viscosity epoxy (Denepox 40, DeNeef America, Inc). A thixd sample was made with a steel pipe with an outside diameter of 5.585 inches in a 6 -inch diameter hole using an epoxy mortar as previously described.

The Denepox 40 and Flexolith were allowed to cure for seven days and the Poly-Plug cured for one day, before the bond strength was measured.

The Poly.Plug had a shear stress of $540 \mathrm{psi}$, although it appeared that only half of the surface area of the pipe was bonded to the polymer concrete. The Flexolith mortar had a shear stress of 1800 psi. The steel pipe glued in with the Denepox 40 started to deform when the stress level at the glue line was $2170 \mathrm{psi}$. The test results indicate that an excellent bond can be obtained with an epoxy adhesive or an epoxy mortar.

Additional tests were conducted to determine if the joints were water tight. Test samples were made as shown in Figure 3. A large pipe cap was then epoxied to the polymer concrete slab to cover the pipe penetration (Figure 4). Water was pressurized within this pipe cap to $15 \mathrm{psig.} \mathrm{If} \mathrm{the}$ bond line between the pipe penetration and the polymer concrete slab had any cracks or separations, they would allow water to seep through to the other side. Water pressure was maintained on the bond line for several days and no leaks were detected. 


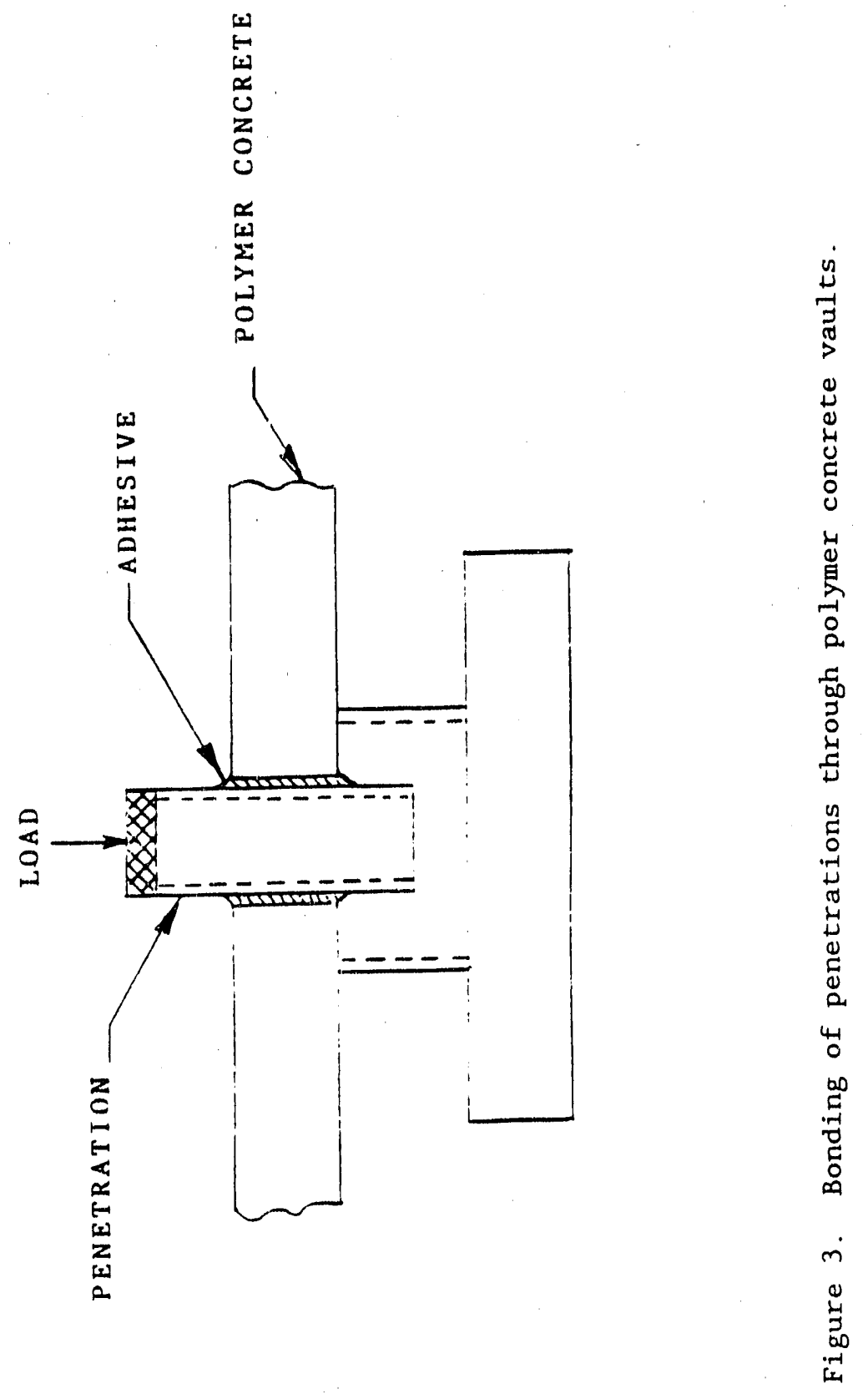




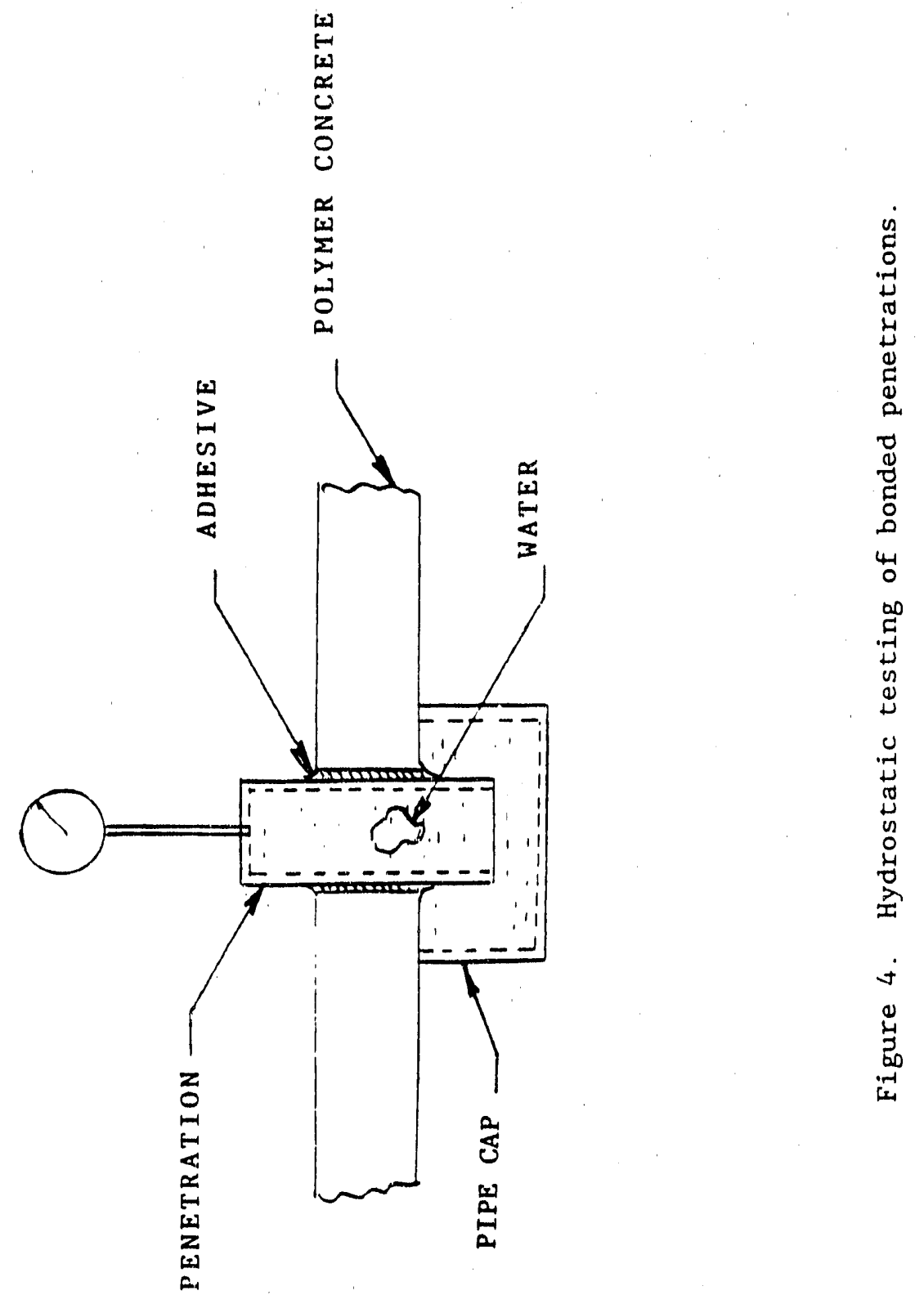




\section{INSTALLING COVERS ON POLYMER CONCRETE VAULTS}

The covers used by the individual utilities must be installed so that they become an integral part of the vault. Specific installation procedures are described in this section.

A. The Brooklyn Union Gas Company

The cover for the BUG vaults was dasigned and cast to be reversible.

This will allow the vault to be right or left handed.

First it is necessary to establish which side of the cover will rest on the vault walls. Then the perimeter of the cover ( 4 to 5 -in. wide) face which is to be bonded to the vault walls will be roughened with an abrasive wheel in a hand held grinder to remove any resin rich areas and/or release agents. The same operation shall be performed on the edges of the vault walls to which the cover is to be bonded.

A mixture of 50 volume percent of silica sand (\#0ON - Morie Company) and 50 volume pexcent of an epoxy gel (Flexolith - Dural International) shall be thoroughly blended using a Jiffy mixer (Jiffy Mixer Co.). This mixture shall be applied to the entire edge of the vault walls approximately $1 / 8$ to $1 / 4 \mathrm{in}$. thick.

The polymer concrete cover shall then be lowered into position and the adhesive shall be allowed to cure for a minimum of 8 hours before additional work shall be continued on the cover which may cause it to move. If there is a mismatch betwee $n$ the cover and vault wall. ends, the adhesive may be applied as thick as 1 inch. However, it should be remembered that the thinner the bond line the better the load transfer across the bond line. 
B. Consolidated Edison Company

The cover used for the Con Ed vault is a Bilco double leaf steel door. It is necessary to remove or at least scratch up the paint with a wire brush on the surfaces that will be bonded to the polymer concrete vault. The polymer concrete surfaces of the vault should also be roughened with an abrasive wheel to remove any resin rich surfaces.

A mixture of 50 volume percent silica sand (\#0ON - Morie Company) and 50 volume percent epoxy gel (Flexolith - Dural International) shall be throughly blended using a Jiffy mixer (Jiffy Mixer Co.). This epoxy mortar shall be applied to the polymer concrete vault surfaces that will be bonded to the steel cover. A bead approximately $1 / 8$ to $1 / 4$ inch thick by 1 inch wide shall be applied. The steel cover shall then be lowered into position and the adhesive shall be allowed to cure for a minimum of 8 hours before additional work shall be continued on the cover which may cause it to move. If it is evident that a thicker strip of adhesive is necessary to fill gaps betwen the polymer concrete vault and the steel cover, the epoxy mortar may be increased to a thickness of $1 / 2$ inch. 
A design study was made to replace the reinforced portland cement concrete vaults (BUG PV -008 and Con Ed GR-6) with precast polymer concrete vaults.

The procedure used for the design was to consider the vaults as a series of plates; cover, sidewall, and foundation slab. Each of the components was analyzed using classical plate theory with the loading resulting from soll pressures, highway loading, and dead weight. This section contains discussions of the loading, material properties, and stress evaluations.

A. Loading

The loading acting on the boxes shall contain three components:

(1) The weight of the box.

(2) The effect of the weight of the soll (unless a specific value is available use $110 \mathrm{lb} / \mathrm{ft}^{3}$ ).

(3) A live load component that shall be taken as one of the following (the design criteria for a particular application should specify which of these are to be considered):

(a) A uniform vertical load of $600 \mathrm{psf}$ (such as required by the NYC building code).

(b) The HS-20 AASHTO loading which consists of the more severe of a uniform lane load of 640 pounds per foot distributed over a ten feet lane width or two concentrated wheel loads of 20,800 pounds each (including a $30 \%$ impact factor) spaced at five feet. Note that because of the dimensions of typical boxes only a single wheel load is considered.

(c) A 15 cubic yard concrete truck, the rear wheels of this truck produce four loads each of the 20,250 pounds and spaced at 5 feet in one direction and 6 feet in the other direction.

The forces acting on each element of the box by these loadings are discussed. 


\section{Forces on Cover}

The cover will. be loaded with the weight of the cover plus any soll overburden placed as a uniform load on the cover plate. Since the cover will generally be close to the surface (the cover is usually about one foot below the ground surface) the highway loading is placed directly on the cover. It is recomnended that the cover be designed for either a uniform live load of 600 psf or a single wheel load of 20,800 pounds placed at the center of the cover. Of course, for boxes that have plan dimensions greater than 10 feet, consideration should be given to placing the 2 or 4 wheel loads (depending on whether the box is designed for HS -20 or the $15 \mathrm{yd}^{3}$ concrete truck) on the cover in a position leading to the highest bending moments.

\section{Forces on Sidewalls}

The loading on sidewalls which are in contact with the soil is taken as the soll pressure (resulting from soll welght and highway loading) component that is normal to the surface of the plate (i.e., the loading on the vertical plates is equal to the horizontal soil pressure at the depth of interest). In all cases the horizontal soll pressure is taken as one half of the vertical pressure. While the actual loading on the wall will vary over the depth of the wall, it is recommended that the wall be designed for a uniform pressure equal to the average loading applied to the wall.

The loading component of the soll pressure due to its own weight $\left(p_{B}\right)$ is:

$$
P_{s}=\gamma z / 2
$$

where, $\gamma=$ soil density in $1 \mathrm{~b} / \mathrm{ft}^{3}$

$z$ - depth below surface in feet

$p_{s}$ - pressure in ps $f$

The loading component for the $15 \mathrm{yd}^{3}$ concrete truck is computed by converting the four wheel loads to uniform loading over an area of 5 feet by 6 feet, and spreading the load by 45 degrees as depth from the surface increases. Of course, the pressure acting on the sidewall is one half of the vertical component of soil pressure. Therefore, the pressure acting on the sidewall is:

$$
P_{c t}-81000 / 2(5+2 z)(6+2 z)
$$


The loading component for the HS-20 loading will be critical for the two wheel loads. This is again taken to act on an area of 6 feet by 1 foot on the surface and to spread out at a 45 degree angle with depth. Therefore, the pressure acting on the sidewall is:

$$
p_{\text {IIs }}-20,800 / 2(6+2 z)(1+2 z)
$$

The uniform pressure of $600 \mathrm{psf}$ is not attenuated with depth so that the resulting load on the sidewall is:

$$
P_{\text {NYC }}=600 / 2-300 \text { psf }
$$

It should be noted that this pressure must be less than the allowable soll bearing pressure. If it is not, the plan dimensions of the box must be increased.

The actual loading on the sidewall will vary linearly over the depth of the wall. It is reconmended that an average unfform loading be used so that the design process may be expedited. Any errors which may result are well within the reliability within which the loads are known.

\section{Forces on Foundation S1ab}

The forces on the foundation slab shall be taken as a uniform pressure equal to the weight of the box plus the weight of soll over the cover plus the total highway load acting on the cover divided by the area of the slab. Therefore,

$$
p_{F s}=\gamma h+\left(W_{B}+W_{B}\right) / A
$$

where, $h$ - depth of soll over cover in feet

$$
\begin{aligned}
& W_{B} \quad-\text { weight of box in pounds } \\
& W_{B} \quad-81000 \text { pounds for concrete truck } \\
& W_{H} \quad-41600 \text { pounds for HS-20 loading } \\
& W_{H} \quad-600 \text { A for NYC building code } \\
& A \quad=\text { plan area of fo idation slab in square feet } \\
& \alpha \quad-\text { soll density of } 110 \mathrm{lb} / \mathrm{ft}^{3}
\end{aligned}
$$




\section{B. Material Properties}

The properties of polymer conciete can be adfusted by a proper selection of resin type, resin content, and fiber characteristics. The most significant properties of the polymer concrete that are used for design are the flexural strength of the $\mathrm{mix}$ and the ductility of the material when subjected to flexural loads. It is recommended that the flexural strength $\left(f_{R}\right)$ be determined by a medulus of rupture test. This test should be continued to failure and the flexural strength $\left(f_{n}\right)$ be determined as the stress

corresponding to the load at the end of the linear portion of the load deflection curve. The design is based on an allowable flexural stress of $\left(f_{R} / 2\right)$. It is further recommended that any material used for the boxes have sufficient ductility so that the area under the load deflection curve between the end of the Ilnear portion of the curve (the point defining $f_{R}$ ) and the fallure load be at least ten times the area under the linear portion of the curve.

OLher strength properties of interest include the shear strength of. the material $\left(v_{F}\right)$ and the modulus of elasticity (E). The modulus of elasticity can be found from the modulus of rupture test required to determine $\left(f_{R}\right)$. Data for some of the polymer concretes used for this study suggest that:

$$
E-800 f_{R}
$$

A separate punching shear test must ba run to evaluate the shear strength. Data obtained during this design study suggest that:

$$
v_{F}=f_{R} / 4
$$

It is recommended that the allowable shear stress in the box be limited to one third of $\left(v_{F}\right)$.

The polymer concrete composite has a density of $1501 \mathrm{~b} / \mathrm{ft}^{3}$. 


\section{Stress Evaluations}

The boxes consist of six plate elements, and it is recommended that classical plate theory be used to evaluate the bending stresses. The loading on the sidewalls and foundation slab will be uniform as discussed in Section A.2 and A.3. The loading on the cover may be either uniform or a point load at the center of the plate as discussed in Section A.1.

Since the boxes are cast monolithically (or in some cases sections of the boxes are connected with foints having strengths equivalent to a monolithic pour), it is recommended that the boundary conditions of adjoining plates be taken as fixed. Therefore, all foundation slabs can be designed as having fixed boundary conditions. Sidewalls will have three sides fixed and the edge adjolning the cover will be fixed if a polymer concrete cover is adequately joined to the sidewall and free if not. The cover will be fixed if the sidewall-cover foint is adequate. If not, the edges of the cover will be simply supported.

Solutions for these load cases are given in tabular form in a reference book by Rudolph Szllard [5].

\section{Experimental Verification}

A box was fabricated of polymer concrete and tested to demonstrate its performance. The box was quarter scale with center-to-center dimensions of 23 inch $\times 17.5$ inch $\times 17.5$ inch and a wall thickness of 1 inch. Tests on the material used for the box indicated a flexural strength of 3581 psi, an elastic modulus of $2,450,000$ psi, and a shear strength of about 800 psi.

The first tests of the box were conducted by evacuating the box thereby subjecting it to a uniform pressure. The maximum vacuum that could be achieved was $170 \mathrm{~mm}$ of mercury resulting in a peak pressure of $11.41 \mathrm{psi}$ (1643 psf). The box was subjected to a complete load-unload cycle. Note that a typical design pressure for this box is about 1000 psf so that the test subjected the box to pressures $60 \%$ higher than design. The results of the experiment indicated: 
(1) There was no observable cracking. It should be noted that any significant cracking would have made it impossible to achieve the vacuum, especially during the second load cycle.

(2) The measured strains and deformations in the box indicated Iinear behavior with complete recovery. The deflection at the center of the larger plate increased from 0.0015 inch at a vacuum of $600 \mathrm{~mm}$ to 0.0053 inch at a vacuum of $200 \mathrm{~mm}$. The measured deflection on the unloading side was 0.0019 inch at a vacuum of $600 \mathrm{~mm}$.

The data contained in Reference 5 was used to perform an analysis of the box. The larger wall has $a(b / a)$ ratio of $(23 / 17.5-1.31)$. Case 80 of the Reference indicates that the maximum bending moment (which occurs at the center of the long support) and the center deflection are:

$$
\begin{aligned}
& M=0.069 P_{0} a^{2} \\
& w=0.022 P_{0} a^{4} / E h^{3}
\end{aligned}
$$

Therefore at the peak pressure of 11.41 psi the predicted values

are :

$$
\begin{aligned}
& \mathrm{M}-0.069 \times 11.41 \times 17.5^{2}-241.1 \text { inch pounds per inch } \\
& \mathrm{w}=0.022 \times 11.41 \times 17.5^{4} / 2450000 \times 1^{3}=0.0096 \text { inch } \\
& \text { The maximum stress in the plate is therefore: } \\
& \qquad \mathrm{f}-6 \mathrm{M} / \mathrm{h}^{2}-6 \times 241.1 / 1^{2}-1447 \mathrm{psi}
\end{aligned}
$$

This stress is below the yleld stress of 3581 psi so that elastic action, as observed, would be expected. The calculated deflection is considerably larger than observed indicating that the plate deformations calculated using the modulus obtained from the modulus of rupture are too large, but on the conservative side. It should be noted that this deflection scaled to full scale would be $(4 \times 0.0096-0.038$ inch). The box deflections will be small and this degree of conservatism is not important. 
The box was next modified by passing a 6 -inch diameter pipe through the center of the large wall. The pipe was bonded to the wall. A second vacuum test was performed and the results were similar. For example, the center deflection at a vacuum of $200 \mathrm{mn} \mathrm{H}_{\mathrm{g}}$ was found to be 0.0054 inch as compared with 0.0053 inch for the first test.

The box was loaded to failure with a concentrated load applied through a 3 -inch diameter pipe centered around the penetration. Strain gauges were placed every 3 inches in the $X$ and $Y$ axis from the center of the box. The measured load deflection curve is shown in Figure 5. The yield load was about 7500 pounds at a deflection of about 0.064 inch. The ultimate load was 12,500 pounds. It is interesting to observe that no catastrophic failure occurred with the load dropping off slowly as the deflection increased. For example, the load corresponding to a deflection of 0.77 inch was found to be 5000 pounds. Concentrated loads scale as the square of the geometric scale factor so that the 81000 pound load of the concrete truck would scale to ( $81000 / 16$ - 5060 pounds). Therefore, the experimental data seem to agree with the design loads within the experimental parameters.

Calculations were performed for the ultimate load experiment by assuming that the load was concentrated at the center (this solution is available). From the data, the maximum moment occurs at the center of the long edge as is:

$$
M=0.1547 \mathrm{P}
$$

Therefore yield would be expected when:

$$
f=6 M / h^{2}-3581 p s i
$$

Solving for the yield load

$$
P=3581 h^{2} / 0.1547 \times 6=3858 \text { pounds }
$$




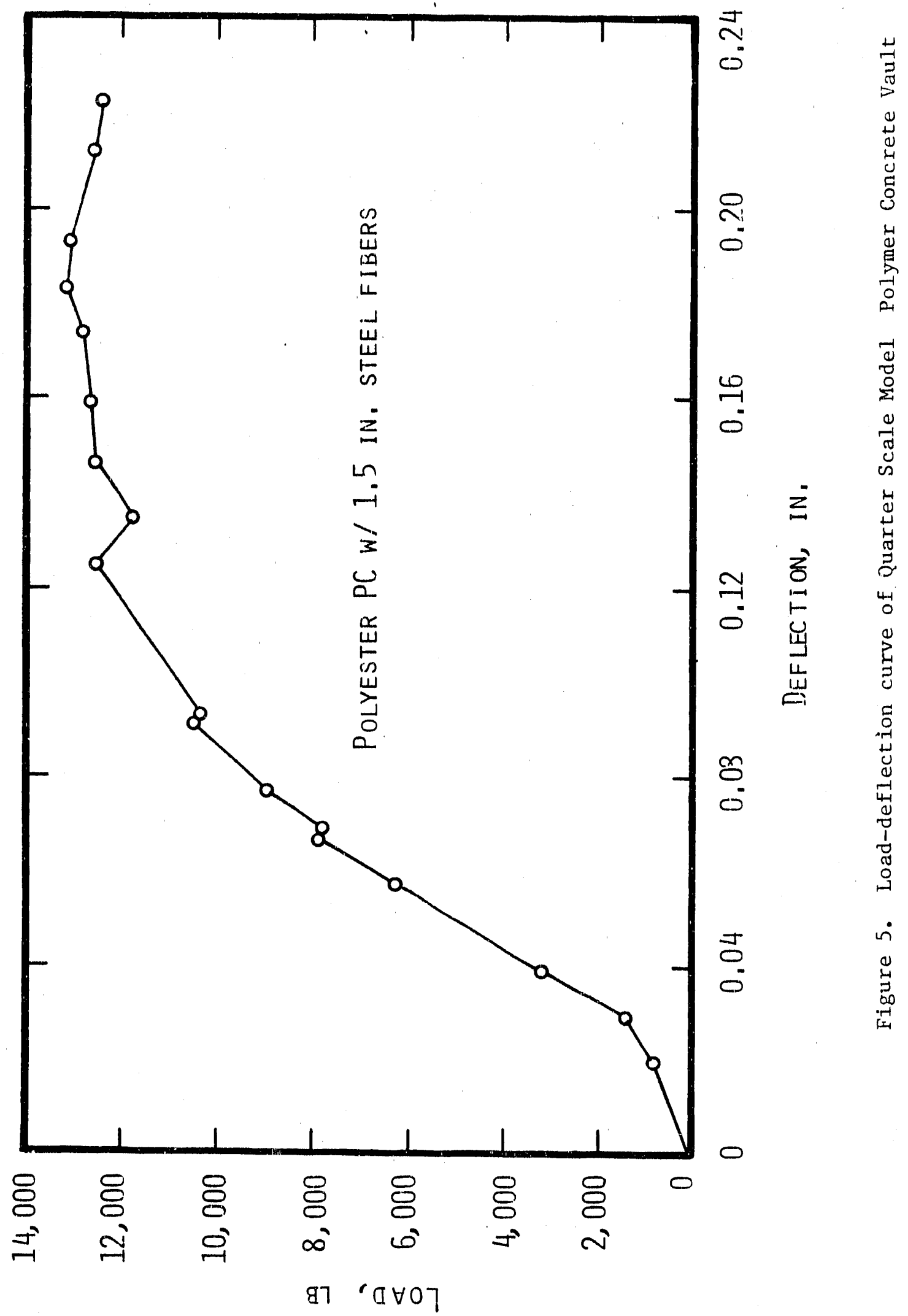


This is about one half of the measured yield load. The low prediction is probably due to the fact that the actual loading is not placed at the center of the plate and that the steel pipe penetration stiffens the plate.

A yleld line analysis [6] was performed and the predicted collapse load of the plate was found to be 21,600 pounds for fixed boundary conditions and 10,800 pounds for simply supported boundary conditions. These computations used the actual location of the loads in the experiment and the yield lires do not intersect the penetration so that stiffening of the plate by the steel pipe will not be a factor. The fact that the measured collapse load is closer to the simply supported boundary conditions indicate that the material is not perfectly ductile to fully develop the plastic hinges along the plate boundary.

\section{E. Designs}

The above methodology is applied to two boxes. One is typical of a Brooklyn Union Gas design and the other is typical of a Consolidated Edison of New York design.

\section{The Brooklyn Union Gas Company}

The Brooklyn Union Gas box measures 7 feet by 6 feet in plan and is 7 feet high. These are clear interior dimensions. There is a cover. connected to the box and the cover contains a clear opening of 2 feet 9 inches square in one corner to recelve a cast iron manhole. The box is designed for the concrete truck or the NYC uniform load whichever is more severe. The top of the cover is about 1 foot below grade. Polymer concrete having a flexural strength greater than $3500 \mathrm{psi}$ is used. Since this value is based on only four samples, a minimum yield of $3000 \mathrm{psi}$ is assumed so that the design flexural stress is 1500 psi.

The cover is 7.33 feet by 6.33 feet (allowing for center line to centerline dimensions) so that the (b/a) ratio is 1.15 . The moment is obtained for both a uniform load and a concentrated load at the center. These are: 


$$
\begin{gathered}
M_{\text {UNIP }}=0.06 P_{0}(6.33)^{2}-2.54 P_{0} \\
M_{\text {COMC }}=0.1432 \mathrm{P}
\end{gathered}
$$

The loading is a uniform load of the 1 foot of soil (110 psf), the cover weight (estimated at 4 inch - $50 \mathrm{psf}$ ), and either the 600 psf or the concentrated wheel load of 20,800 pounds. The moments due to each of these are:

$$
\begin{aligned}
& M_{8011}=2.54 \times 110-279.4 \mathrm{in} . \text { pounds } / \mathrm{in} . \\
& M_{p c}-2.54 \times 50-127.0 \mathrm{in} . \text { pounds/in. } \\
& M_{600}=2.54 \times 600-1524 \mathrm{in} . \text { pounds/in. } \\
& M_{20800}=0.1432 \times 20800-2978 \mathrm{in} . \text { pounds } / \text { in. }
\end{aligned}
$$

Therefore the design moment is:

$$
\mathrm{M}_{\text {COVER }}-279.4+127+2978-3384 \text { in pounds/in }
$$

The required cover thickness is:

$$
\mathrm{h}_{\mathrm{COVER}}-(6 \times 3384 / 1500)^{1 / 2}-3.7 \text { inch }
$$

A cover thickness of 4 inches is used to account somewhat for the manhole cutout. Note that the cover can be analyzed as two plates each with a free edge along the cutout, fixed edges along the other three boundaries, and carrying half the applied loading. The 4 inch thickness is adequate for this case. At the request of Brooklyn Union Gas, the cover thickness was increased to 5 inches.

The long sidewall is 7.33 feet square (center to center) resulting in $a(b / a)$ ratio of 1.00 . The bending moment caused by a uniform load is:

$$
M_{\text {UIIP }}=0.0513 \text { Po }(7.33)^{2}=2.886 \text { Po }
$$

The top of the wall is 1 foot and the bottom is 8.5 feet below the surface so that the pressures at the top and bottom of the wall (from Eq. 1 and 2) are: 


$$
\begin{aligned}
& \text { DTOP }=110 \times 1 / 2+81000 / 2(5+2)(6+2)=778 \text { psf } \\
& \text { PBOTTOM }-110 \times 8.5 / 2+81000 / 2(5+17)(6+17)-548 \text { fisf } \\
& \text { The average pressure is } 663 \text { psf. The maximum bending moment is: } \\
& \text { M }_{\text {WALL }}-2.886 \times 663-1913 \mathrm{in} \text {. pounds } / \text { in. } \\
& \text { The required wall thickness is: }
\end{aligned}
$$

hWALL $-(6 \times 1787 / 1500)^{1 / 2}-2.77$ inch

At the request of The Brooklyn Union Gas, a wall thickness of 4 inches will be used in the final design to allow for installation of expansion bolts for the ladder and internal piping.

The foundation slab has the same dimensions as the cover so that the same moment equations apply. The calculated weight of the box is:

$$
\begin{aligned}
& W_{B}=150(6.5 \times 7.5 \times 5 / 12+2 \times 7.5 \times 7.5 \times 4 / 12+ \\
& 2 \times 6.5 \times 7.5 \times 4 / 12+6.5 \times 7.5 \times 5 / 12)-16,590 \text { pounds }
\end{aligned}
$$$$
\text { Therefore, the uniform load on the slab is (from Eq. 5): }
$$$$
\text { FOUND }-110 \times 1+(16590+81000) /(6.5 \times 7.5)-2112 \mathrm{psf}
$$

Note that the required soil bearing pressure is 2112 psf.

The maximum bending moment is:

$$
\mathrm{M}_{\text {Found }}-2.54 \times 2112-5364 \text { in. pounds/in. }
$$

The required slab thickness is:

$$
{ }^{\mathrm{k}} \text { FOUND }=(6 \times 5364 / 1500) 1 / 2-4.63 \text { inch }
$$

A thickness of 5 inch was used for the final design. A drawing of the designed vault is given in Appendix $A$. 


\section{Consolidated Edison of New York'}

The Consolidated Edison box measures 6 feet- 1 inch by 4 feet in plan and is 2 feet - 8 inch high. These are clear interior dimensions. A steel butler type door sits on top of the box so that there is no polymer concrete cover. The box is designed for the HS-20 or the NYC uniform load whichever is more severe. The top of the cover is at grade. Polymer concrete having a flexural strength of at least $3500 \mathrm{psi}$ is used. Since this value is based on only four samples, a minimum yield of 3000 psi is assumed so that the design flexural stress is 1500 psi.

The long sidewall is 6.25 feet by 2.83 feet (center to center) resulting in $a(a / b)$ ratio of 0.453 . Since there is no cover built integral with the sidewalls, the top of the plate is assumed to be free and the other three sides fixed. The bending moment caused by a uniform load is:

$$
M_{\text {UNIF }}=0.2370 p_{0}(2.83)=1.898 p_{0}
$$

The top of the wall is $1 / 4$ foot below grade and the bottom is 3 feet below the surface so that the pressures at the top and bottom of the wall (from Eq. 1 and 3) are:

$$
\begin{aligned}
& \text { PTOP }=110 \times 0.25 / 2+20800 / 2(6+0.5)(1+0.5)-1080 \text { psf } \\
& \text { PBOTTOM }-110 \times 3 / 2+20800 / 2(6+6)(1+6)-289 \mathrm{psf} \\
& \text { The average pressure is } 685 \mathrm{psf} \text {. The maximum bending moment is: } \\
& \text { M }_{\text {WALL }}-1.898 \times 685-1300 \mathrm{in} \text {. pounds } / \text { in. } \\
& \text { The required wal1 thickness is: } \\
& \text { hWALL }=(6 \times 1300 / 1500)^{1 / 2}-2.25 \text { inch } \\
& \text { A wall thickness of } 2.25 \text { inches was used for the final design. }
\end{aligned}
$$


The foundation slab has the dimensions of 6.2 feet by 4.5 feet. The moment in the slab due to a uniform load is:

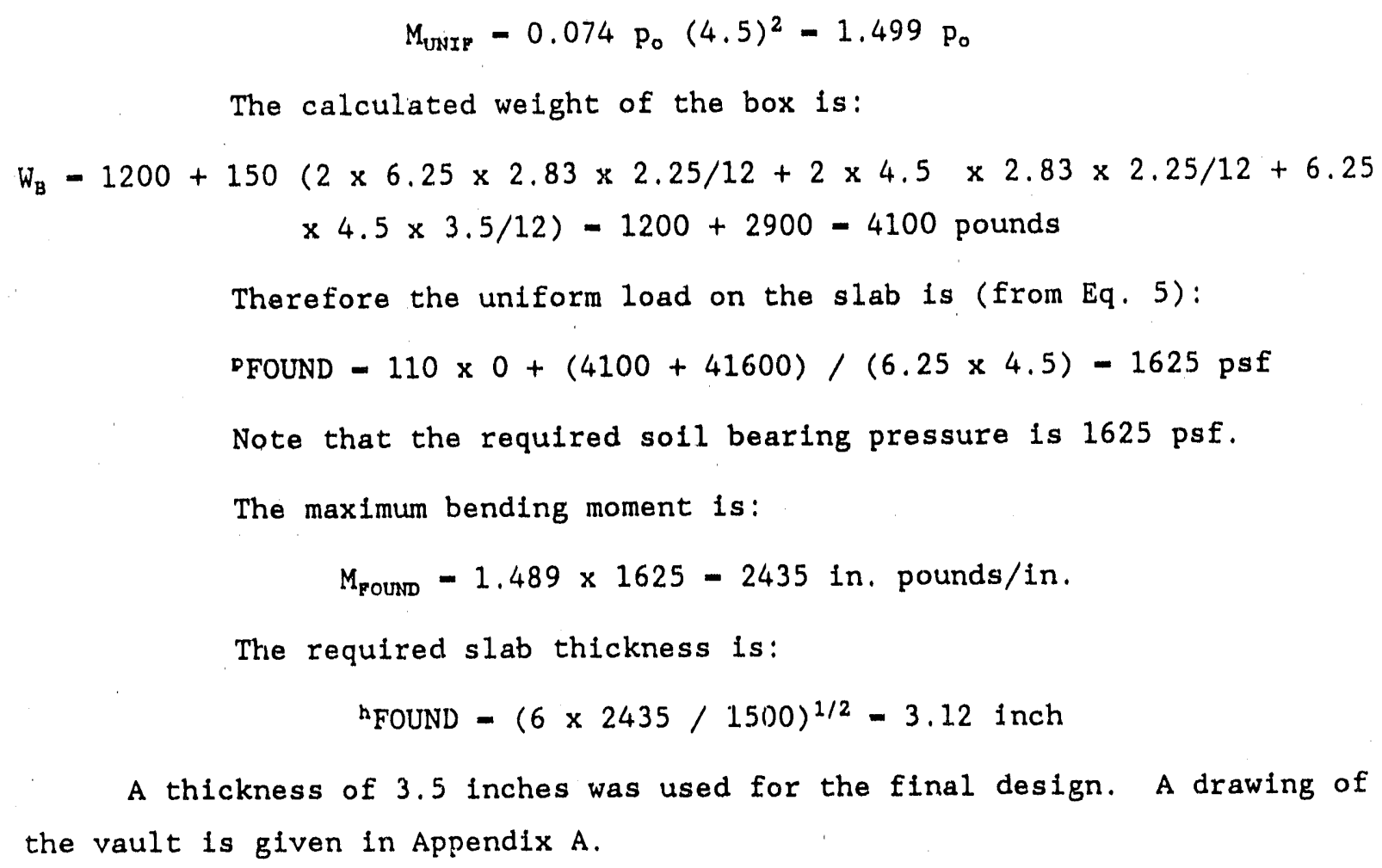


The polymer concrete vaults have thinner wall, base, and cover thicknesses than reinforced portland cement concrete vaults. Therefore, if the ground water is higher than the midpoint of the vault height it will be buoyant. Whenever this situation occurs 1 will be necessary to anchor the vault to a ballast slab t.s prevent it from floating.

The ballast slab can be placed at the bottom of the pit of reinforced portland cenent encrete. It can be poured in place if desired. Then the polymer concrete pit is lowered on top of the ballast slab when it is cured and can be anchored in place with six 1 -inch diameter threaded rods epoxied in place.

For example: if the BUG vault is to be placed in an area where the ground water level would be at the top of the vault it will be necessary to have a concrete slab that is 1.25 feet thick of the same external dimensions as the vault ( $7 \mathrm{ft} .-8 \mathrm{in}$, by $6 \mathrm{ft} .8-\mathrm{in.}$ ).

Six 1.25 inch dia holes should be drilled through the base of the polymer concrete vault into the concrete ballast slab ( 8 to 12 inches deep). An epoxy adhesive is poured into the hole about $1 / 2$ of the total height of the hole. A 1-inch diameter threaded rod is placed in each hole with the epoxy and held in place until the epoxy is fully cured. The total weight of the vault will now be over 25,000 lbs and it will no longer be buoyant. 
VIII. SPECIFICATIONS FOR PRECAST POLYMER CONCRETE VAUL'TS

This specification may be used to order precast polymer concrete vaults for gas regulator stations. The design drawings for such vaults shall be included as part of the specification package. This spectefication has been recommended for Consolidated Edison Company of New York "Gas Regulator Manhole Type GR-6" and for The Brooklyn Union Gas Company "Precast Pit for Governor Pit and Gate Station Monitor Pit, $7 \mathrm{ft}$. by $6 \mathrm{ft}$. by $7 \mathrm{ft} . "$

\section{A. Material Design Formulation}

The following formulation is an optimized mix design that was used to obtain the physical property measurements used for the engineering design data.

\section{Material}

Coarse stone, $1 / 4$ inch $\max$ traprock

$1 / 2$ inch $\max$ traprock

Silica sand, graded, TC 472.-81

Silica flour

Fibers, steel ribbed - $11 / 2$ inches

Resin, orthophthalic polyester

$$
\text { Quantity, wt Percent }
$$

13.5

13.5

40.5

13.5

9.0

10.0

Notes 1. Silaceous river gravel of equal gradation may be substituted for the traprock.

2. All coarse stone and silica sands must have a maximum of 0.5 wt 8 moisture.

3. The polyester resin must contain 1 wt \& silane coupling agent. (gamma-me thacryloxypropyl-trime thoxysilane, A174).

4. The curing system based on the resin consists of 0.5 wt 8 cobalt naphthenate and 1.2 wt 8 methyl ethyl ketone peroxide.

5. The optimized data were obtained with Reichhold Chemical Company resin $7517-8 \mathrm{~A}$ and this is the only approved resin at this time.

6. The density of the composite should be approximately $150 \mathrm{lb} / \mathrm{ft}^{3}$. 
B. Physical property Measurements of the Cured Polymer Concrete Composite

The flexure strength of the cured polymer concrete composite is the most critical property requirement for the engineering design. The minimum flexure strength required is 3500 psi as measured by the modulus of rupture test (ASTM C78). In addition, it is necessary for the composite to be ductile to avold the possibility of a catastrophic fallure. Therefore, the area under the load-deflection curve beyond the yleld point must be at least ten times the area under the linear portion of the curve.

Al1 precasters should be required to submit the above test results from at least four $2-1 n$, by $2-1$, by $12-1 n$, beams cast with every vault as a quality control standard. The average value of flexure strerigth shall be 3500 ps 1 and the average area under the load deflection curve beyond the yleld point shall be at least 10 times the area under the linear portion of the curve.

The polyester resin used in this mix design is a very slow curing system. Therefore $i t$ is recommended that demolding should not be attempted for at least 8 hours after the vault has been cast. 


\section{Manufacture of Polymer Concrete Vaults}

A purchase order was awarded to Hardinge Bros., Elmira, New York by BNL. to manufacture two sets of polymer concrete vaults for The Brooklyn Union Gas Company and the Consolidated Elison Company of New York.

A set of molds were construoted of plywood and framing lumber by a subcontractor of Hardinge Bros. After the first polymer concrete vault was cast for the Consolidated Edison Company of New York, it was concluded that all of the molds were too weak to prevent bowing of the sides and top during casting. In addition, sone changes in the design of the vaults were made which necessitated changes in the molds. Therefore, Hardinge Bros, reworked the molds to insure that the walls could be cast with uniform thicknesses and incorporated the design changes required by the Consolidated Edison Company of New York.

After the first vault and cover were cast using the formulation developed by BNL, Hardinge Bros, were reluctant to cast the second set unless the resin could be changed to an epoxy. Numerous flexure beam samples were cast by Hardinge BCOS, and BNL (Section IIIA) using several different epoxy formultions. It was finally concluded that the ductility of the epoxy polymer coneretes that were tested was not as good as that of the polyester polymer concrete that BNL had designed. This indicated that the epoxy polymer concrete could not maintain a load beyond the yield point and this brittle behavior could result in a catastrophic fallure of the vault. Hardinge Bros. concluded that the second set of vaults should be cast with the prlyester polymer concrete designed by BNL to meet the specifications of design.

When the castings were completed they were usually inspected by representatives of BNL, BUG, and Con Ed. Shipment of the vaults to the individual utilities was completed in mid-May 1990. 
1. "Gulde for the Use of Polymers in Concrete," ACI 548. IR-86, Amertcan Concrete Institute, 1986.

2. Fontana, J, J, and Zeldin, A, N, , Concrete Polymer Materials as Alternate Materials of Construction for Geothermal Applications-Field Test Evaluations, ASTM 717, American Society for Testing and Materials, 1981 .

3. Kukacka, L. E., and Fontana, J, J., Polymer Concrete Patching Materials, Final Report, FHWA 77-11 Vol. II, 1977.

4. Fontana, J. J., Insulating LNG Storage Tank Containment Dikes with a Lightwelght Polymer Concrete, BNL 40.064, 1987.

5. Szilard, R., Theory and Analysis of Plates, Prentice Hall, 1974.

6. Wang, C, and Salmon, C., Reinforced Concrete Design, Intext Educational Publishers. 
APPENDTX A

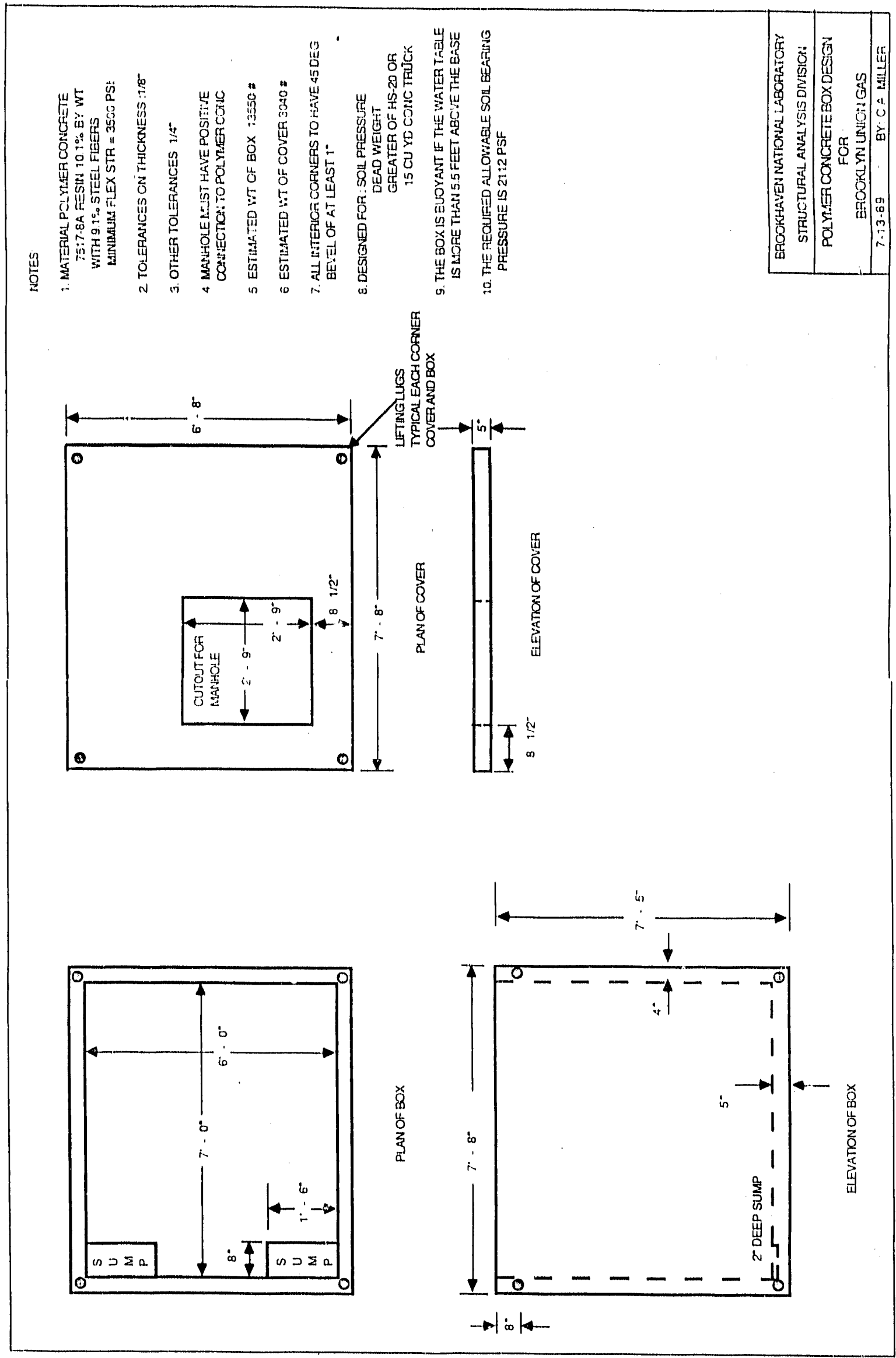


APPENDIX A (cont.)

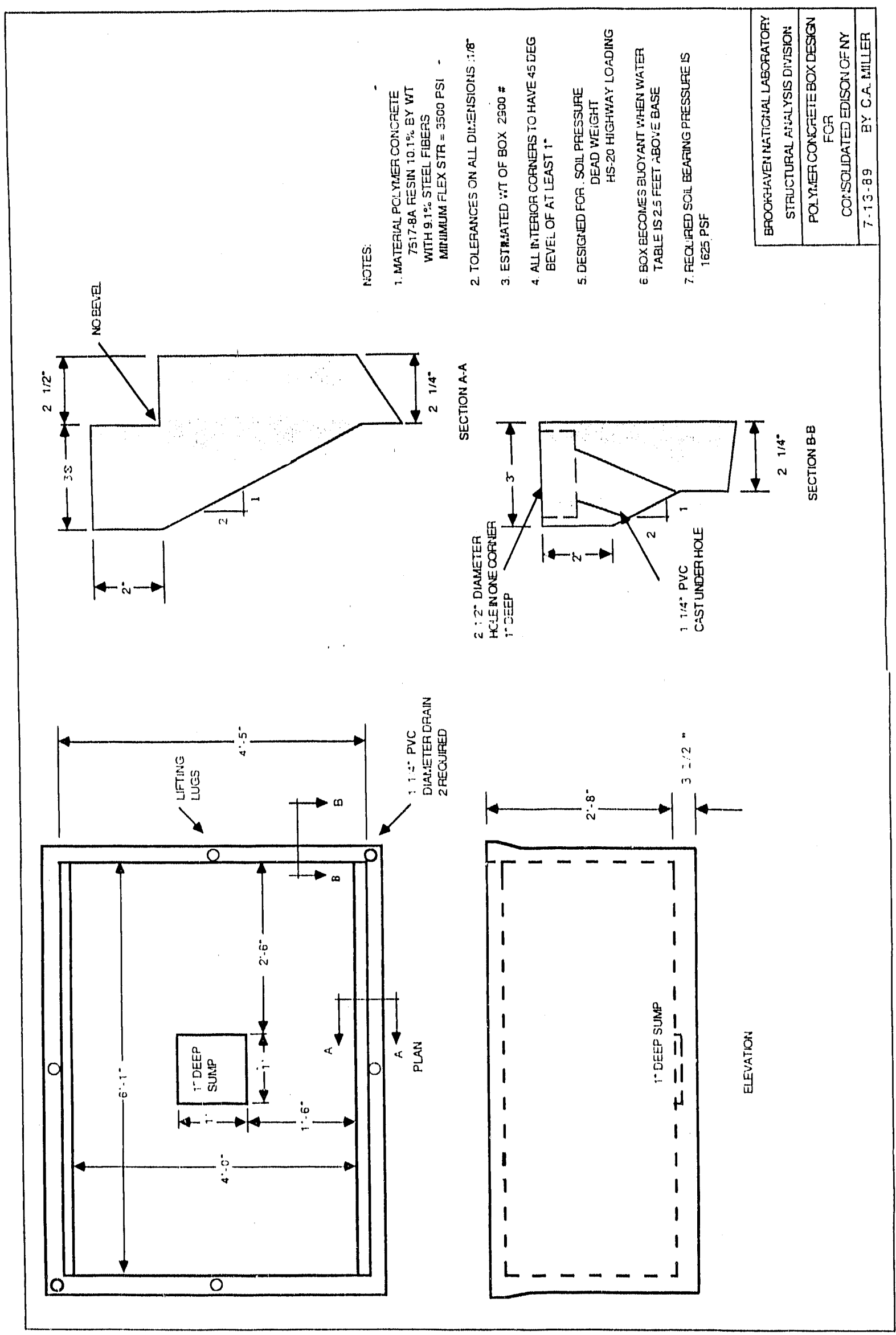


AṔPENDIX B

MATERIAL SUPPLIERS

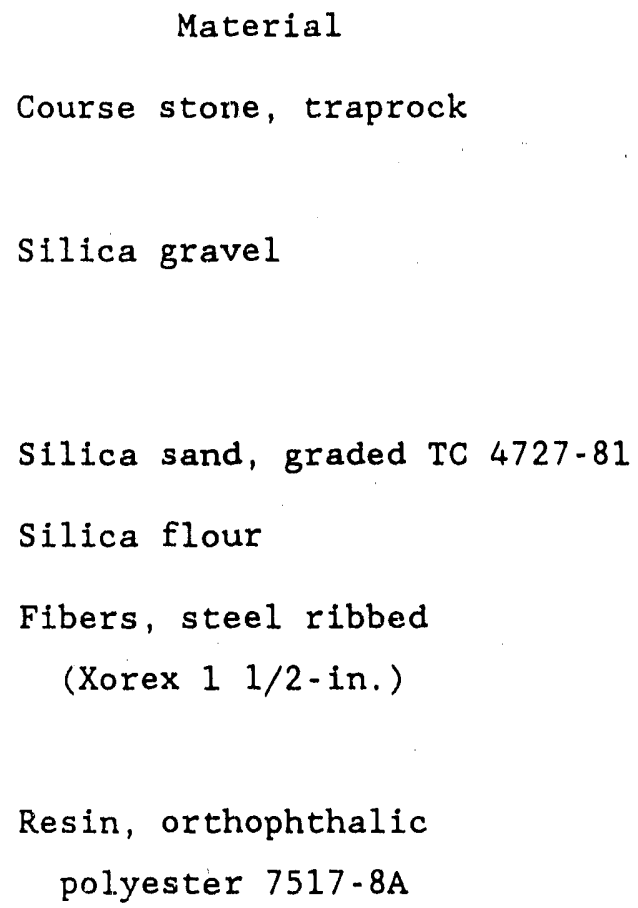

Supplier

Lonestar Industries

Noyak, New York

The Morie Company, Inc.

1201 N. High Street

Millville, New Jersey 08332

The Morie Company, Inc.

The Morie Company, Inc.

Ribbon Technology Corp.

825 Taylor Station Road Gahanna, Ohio 43230

Reichhold Chemical Co.

800 Capitola Drive

Research Triangle Park

Durham, N.C. 27709

Dural International

95 Brook Avenue

Deer Park, N.Y. 11729 

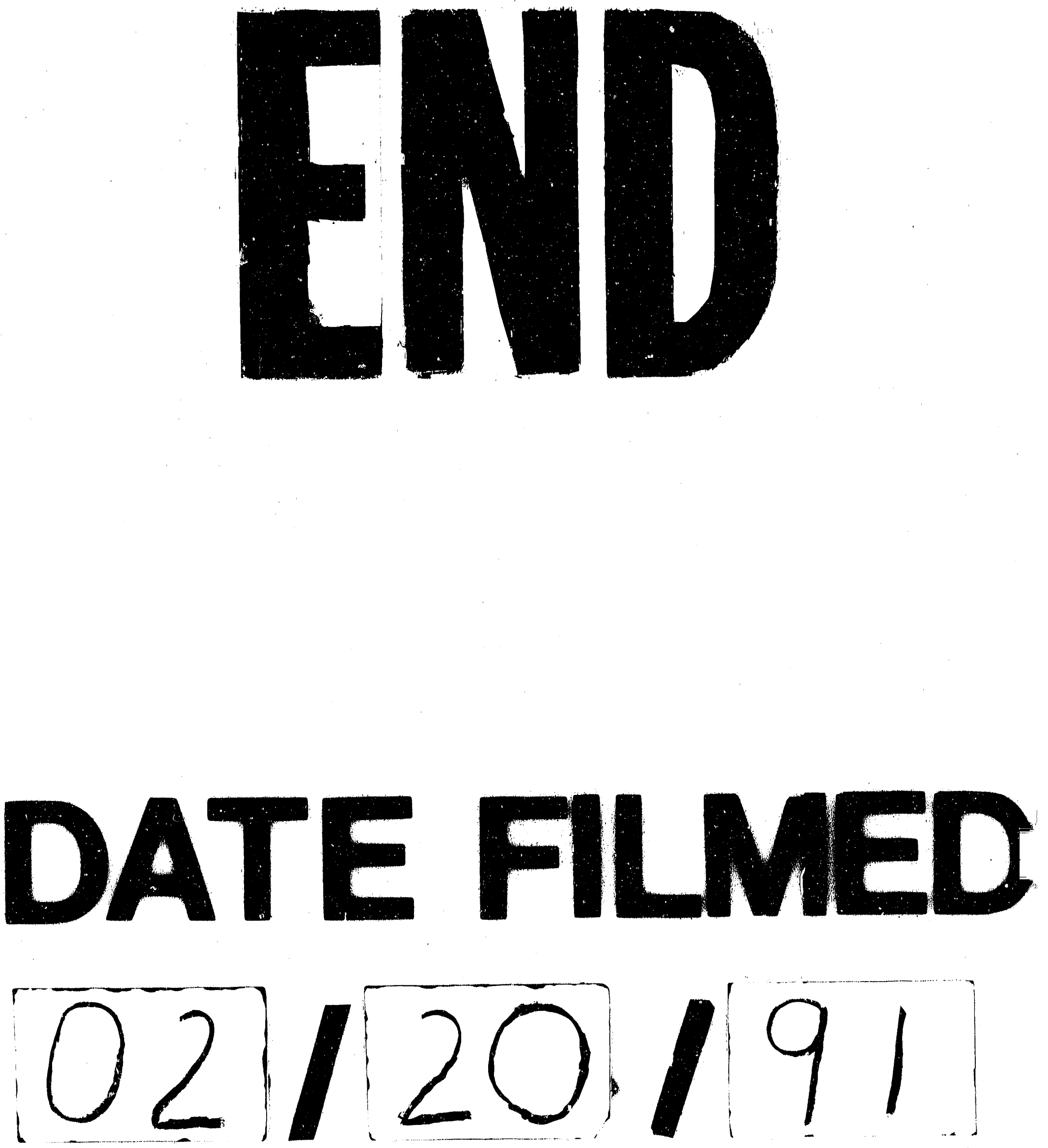
